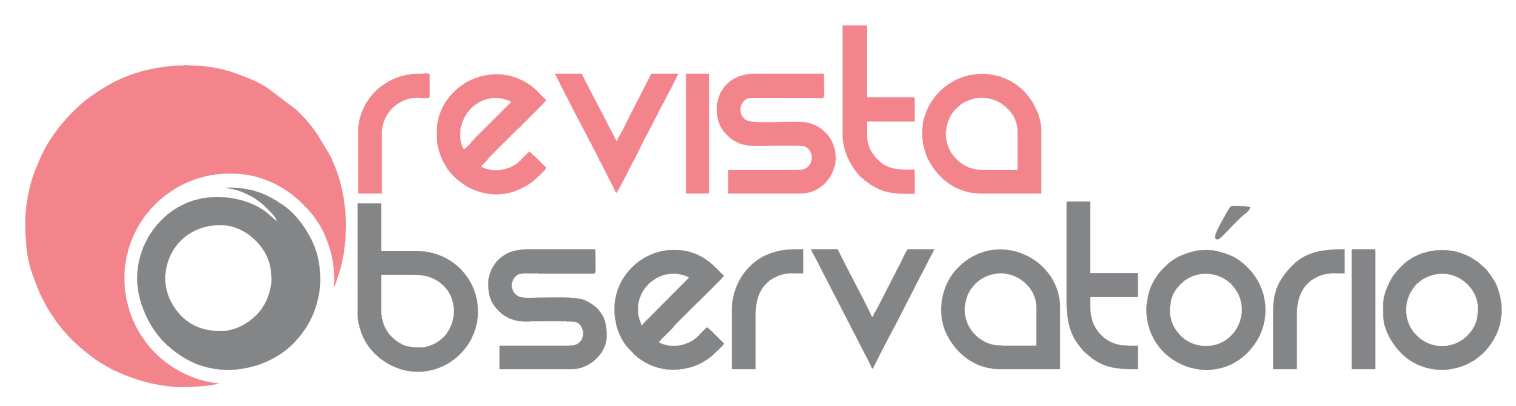

ISSN n² 2447-4266

Vol. 5, n. 1, Janeiro. 2019

DOI: http://dx.doi.org/10.20873/uft.2447-4266.2019v5n1p396

\section{A PROMOÇÃO DA TRANSPARÊNCIA E DO ACESSO À INFORMAÇÃO E DADOS PÚBLICOS VIA INTERNET: um estudo no Estado do Tocantins}

THE PROMOTION OF TRANSPARENCY AND ACCESS TO INFORMATION AND PUBLIC DATA ON THE INTERNET: a study in the State of Tocantins

LA PROMOCIÓN DE LA

TRANSPARENCIA Y DEL ACCESO A LA INFORMACIÓN Y DATOS PÚBLICOS VIA INTERNET: un estudio en el Estado de Tocantins

\author{
Suzana Gilioli da Costa Nunes ${ }^{1}$ \\ Nelson Russo de Moraes ${ }^{2}$ \\ Romário Rocha do Nascimento ${ }^{3,4}$
}

\title{
RESUMO
}

A construção de uma sociedade mais justa, livre e solidária depende da efetiva cooperação e participação dos cidadãos. Esta pesquisa objetivou analisar a efetiva utilização da Internet como um mecanismo promotor da transparência e do acesso à Informação e Dados Públicos, pela população do Tocantins, especificamente por meio dos Portais da Transparência dos municípios. Para a amostra, foram escolhidos os maiores 25 municípios do estado do Tocantins e analisadas as prestações de contas públicas (na Internet) destes municípios, por meio de navegação orientada por uma estrutura de 32 aspectos de análise de acordo com os princípios da teoria da comunicação e o Manual de

1 Doutorado em Administração, Mestrado em Gestão da Qualidade, graduado em Administração, docente da gradução em Administração/Mestrado em Gestão de Políticas Públicas. E-mail: suzanagilioli@yahoo.com.br.

2. Doutorado em Comunicação e Cultura Contemporânea,Mestre em Serviço Social, Graduado em Administração, E-mail: nelsonrusso.unesp@gmail.com.

3 Graduação em Administração. E-mail: admrocha13@gmail.com.

${ }^{4}$ Endereço de contato com os autores (por correio): DTE na UFT/CAMPUS PALMAS, endereço: QUADRA 109 NORTE, AV. NS 15, ALCNO 14 - PLANO DIRETOR NORTE | 77001-090 | Palmas/TO 


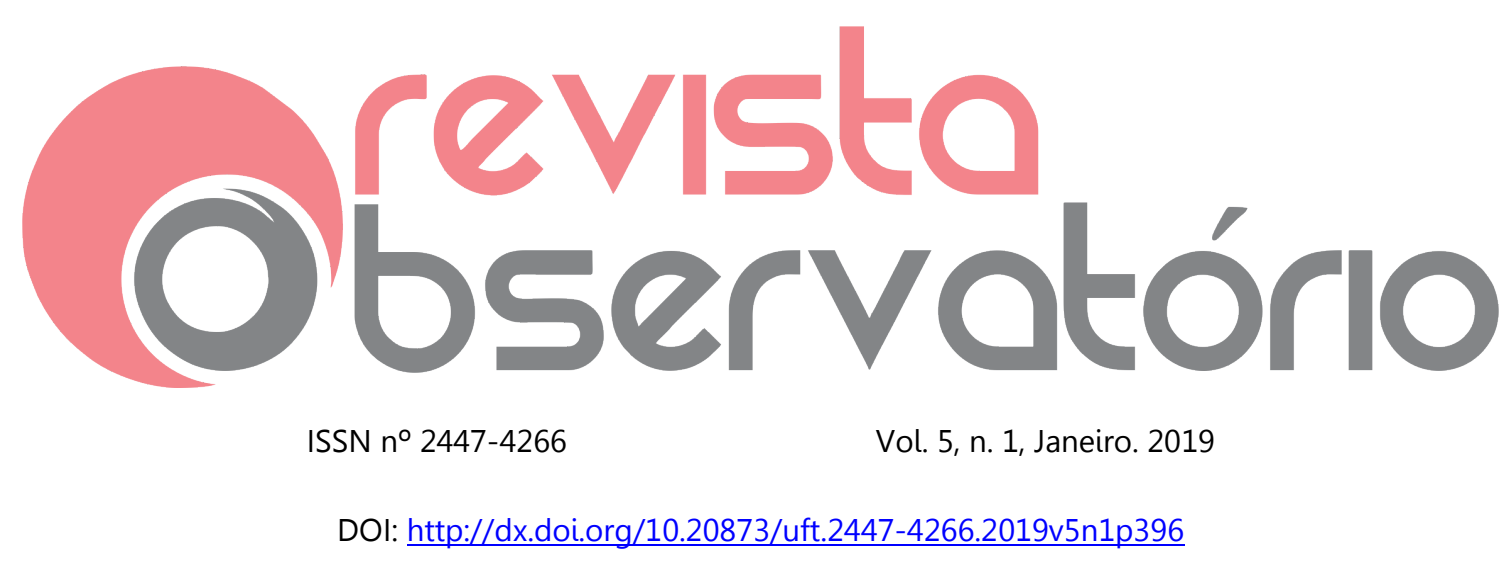

Acessibilidade do Governo Brasileiro (aplicável à navegação nos sites da gestão pública no Brasil).

PALAVRAS-CHAVE: Portal da Transparência; Tocantins; Internet, contas públicas.

\section{ABSTRACT}

Building a more just, free and supportive society depends on the effective cooperation and participation of citizens. This research aimed to analyze the effective use of the Internet as a mechanism to promote transparency and access to Public Information and Data, by the population of Tocantins, specifically through the Transparency Portals of the municipalities. For the sample, the largest 25 municipalities in the state of Tocantins were chosen and the public accounts (on the Internet) of these municipalities were analyzed through navigation guided by a structure of 32 aspects of analysis according to the principles of communication theory and the Brazilian Government Accessibility Manual (applicable to navigation on public management sites in Brazil).

KEYWORDS: Transparency Portal; Tocantins; Internet, public accounts.

\section{RESUMEN}

La construcción de una sociedad más justa, libre y solidaria depende de la efectiva cooperación y participación de los ciudadanos. Esta investigación objetivó analizar la efectiva utilización de Internet como un mecanismo promotor de la transparencia y del acceso a la Información y los datos públicos, por la población de Tocantins, específicamente a través de los Portales de la Transparencia de los municipios. Para la muestra, fueron elegidos los mayores 25 municipios del estado de Tocantins y analizadas las prestaciones de cuentas públicas (en Internet) de estos municipios, por medio de navegación orientada por una estructura de 32 aspectos de análisis de acuerdo con los principios de la teoría de la comunicación y el Manual de Accesibilidad del Gobierno Brasileño (aplicable a la navegación en los sitios de la gestión pública en Brasil). 


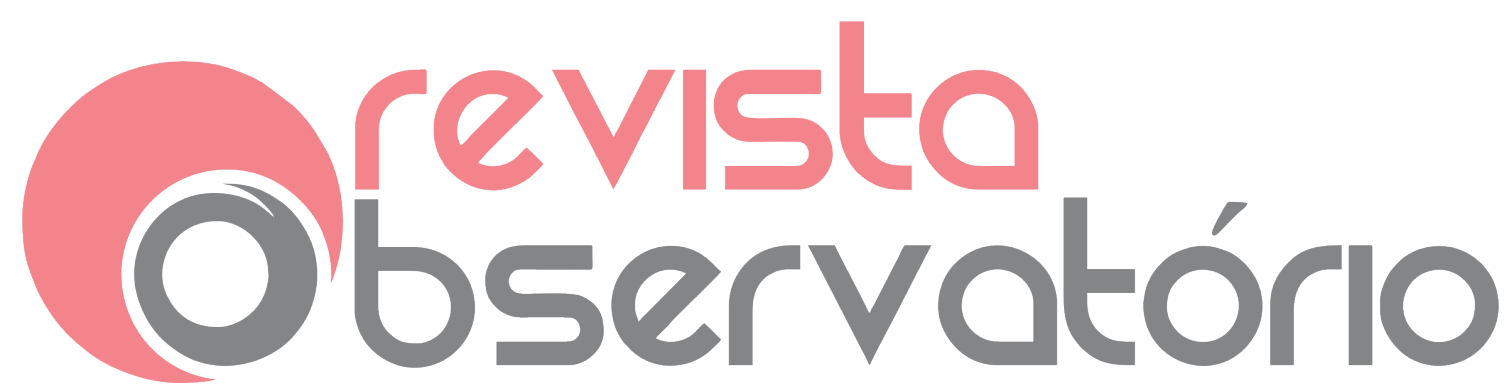

ISSN n² 2447-4266

Vol. 5, n. 1, Janeiro. 2019

DOI: http://dx.doi.org/10.20873/uft.2447-4266.2019v5n1p396

PALABRAS CLAVE: Portal de la Transparencia; Tocantins; Internet, cuentas públicas.

Recebido em: 30.09.2018. Aceito em: 15.11.2018. Publicado em: 14.01.2019. 


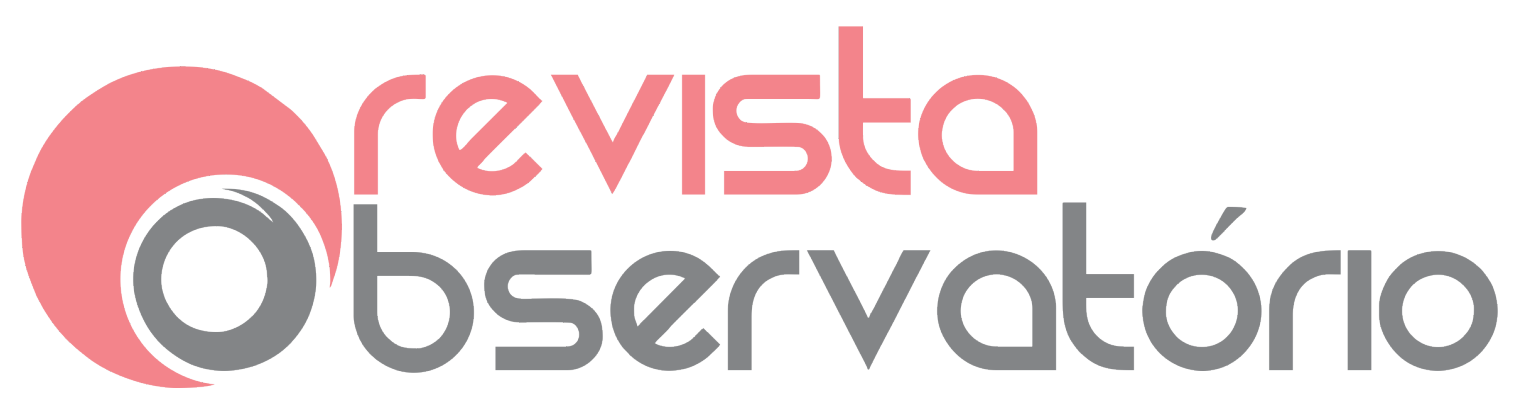

ISSN n² 2447-4266

Vol. 5, n. 1, Janeiro. 2019

DOI: http://dx.doi.org/10.20873/uft.2447-4266.2019v5n1p396

\section{INTRODUÇÃO}

O século XXI apresenta uma característica marcante: a velocidade das mudanças, essas ocorrem em todas as áreas do conhecimento humano devido à enorme produção e propagação de informações. É certo que estamos passando por uma revolução tecnológica e de comunicação social, que impulsiona a interação das relações humanas e forma um novo tipo de sociedade, a da informação.

Os desafios da administração contemporânea são decorrentes das mudanças de paradigmas no mundo. Uma visão mais abrangente do mundo atual nos permite vislumbrar as transformações que a denominava "sociedade do conhecimento" ou "sociedade da informação" está provocando na sociedade mundial. O ritmo do processo da globalização, numa velocidade cada vez maior, especialmente com a utilização das redes digitais, está provocando e exigindo mudanças profundas no Estado, nos governos, administrações públicas, na sociedade, nos âmbitos: local, regional, nacional e global. (MATIAS-PEREIRA, 2009, p. 2)

Nesse processo de evolução mundial, verificam-se diferentes tipos de poder, antigamente detinha o poder quem possuía armas, depois os grandes proprietários de terra, em seguida os industriais; e em um passado recente, mas ainda presente, o poder está com quem tem dinheiro; contudo, adentramos uma era em que o poder está agregado a quem controla a informação: é a Era do Conhecimento.

Essa nova realidade e o surgimento das tecnologias da informação modificaram profundamente $\mathrm{o}$ trabalho dentro das organizações e fora delas. A adoção das redes internas e externas globalizou e democratizou o acesso a diversos dados e informações. Nessa corrente ambiente, quanto melhor estrutura forem as ferramentas tecnológicas, mais informado e poderoso se 


\section{Observisto \\ ISSN n² 2447-4266 \\ Vol. 5, n. 1, Janeiro. 2019 \\ DOI: http://dx.doi.org/10.20873/uft.2447-4266.2019v5n1p396}

torna o usuário, seja ele uma pessoa, organização ou Estado. A informação tornou-se uma espécie de fonte de energia, um combustível valioso para a sociedade, que aglutina esforços e direciona os novos rumos a seguir.

Trata-se, portanto, de uma mudança de cultura em face das facilidades de acesso a dados, informações e novos produtos em nível global - fomentados pelo barateamento dos custos de produção e distribuição. Para Castells (1999) há uma quebra de paradigma, uma revolução da informação, cujo cerne das transformações são as novas tecnologias da informação, processamento e comunicação.

Esse paradigma acaba por exigir o desenvolvimento de novas formas de organização, mais ágeis e mais horizontais, pautadas na flexibilidade e na virtualidade, que busquem estabelecer uma comunicação em rede e que vise o aprendizado conjunto e o compartilhamento dos conhecimentos estabelecidos.

\subsection{Justificativa e Relevância}

Nesse contexto sociotecnológico, é possível visualizar que as relações entre o Estado e a sociedade civil estão se aperfeiçoando. As sociedades contemporâneas exigem cada vez mais transparência nas ações do governo, o exercício do cargo público com ética e a aplicação dos recursos públicos de forma eficiente e em conformidade com as necessidades da população. Para tanto, o controle social apresentou-se como uma pauta importantíssima a ser abordada, essa tem avançado muito nos órgãos públicos e na iniciativa privada, revelando um esforço conjunto para despertar o espírito mais participativo e alcançar um ambiente menos corrupto no Brasil.

Para efetivação do controle social, algumas ações que estimulam a sociedade civil a monitorar e fiscalizar a execução das atividades do Estado 


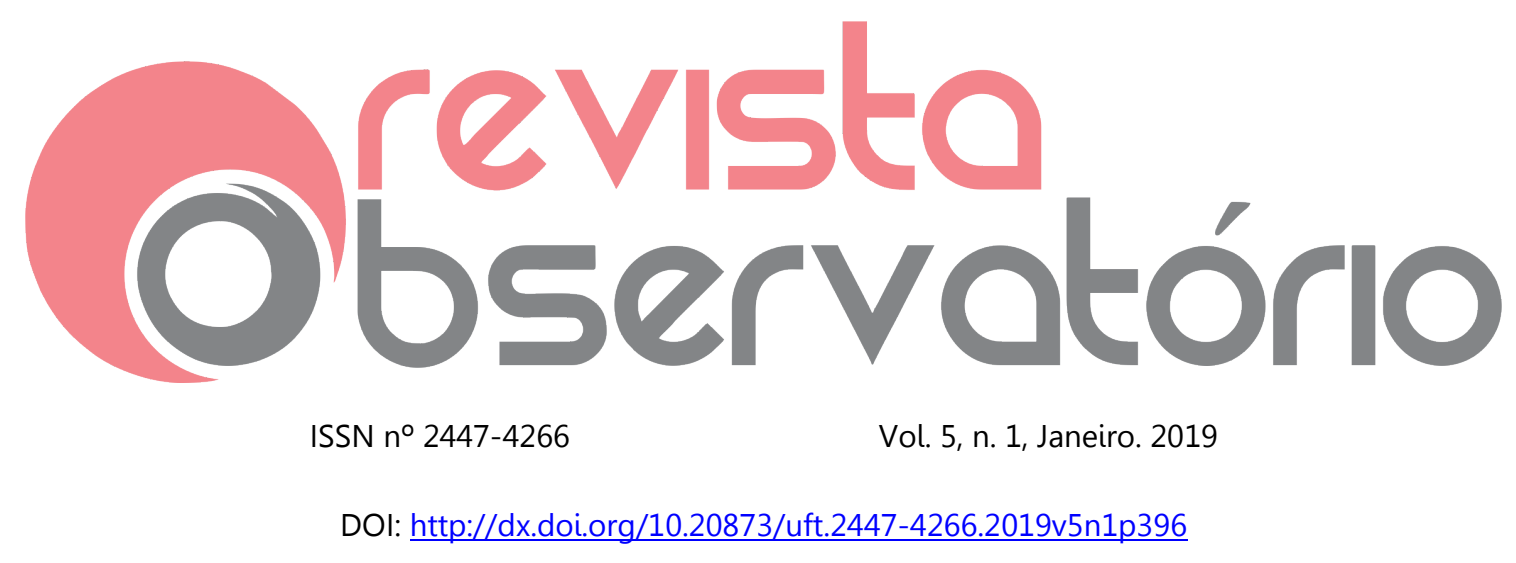

começaram a ser pensadas para a construção de um novo modelo de relações Estado - Cidadão baseado na colaboração, informação, transparência, garantia de direitos e na simplificação e qualidade no acesso aos serviços públicos.

Tais desígnios passaram a ser executadas na forma da lei, já que é papel do Estado estabelecer relações justas e equilibradas com o cidadão por meio da promoção, apoio e participação em ações de responsabilidade social de cidadania e de incentivos voltados para o controle social e combate a corrupção.

Nesse quadro, as Tecnologias de Informação e Comunicação - TICs, em especial a Internet, surgem como um mecanismo para que proporciona um respaldo para a efetivação do controle social, já que fiscalização presencial torna-se cada dia mais inviável.

Diante da importância da participação da sociedade na gestão dos recursos públicos e considerando a informação como um rico instrumento para que o cidadão possa exercer efetivamente o controle social, entende-se que a discussão da temática que aborda a participação da população a partir do acesso a Informação por esse meio Internet é necessária, visto que, a construção de uma sociedade mais justa, livre e solidária depende da efetiva cooperação e participação dos cidadãos.

Assim, a execução deste trabalho de pesquisa acadêmica mostra-se atual e de extrema relevância, pois se faz necessário entender como esse mecanismo é utilizado e quais são as possíveis dificuldades que têm impedido ou prejudicado o cidadão de exercer o tipo de controle social que é fomentado pelo acesso às informações públicas.

\subsection{Problemática}

Após a aprovação da Lei de Acesso à Informação (LAl), houve um avanço 


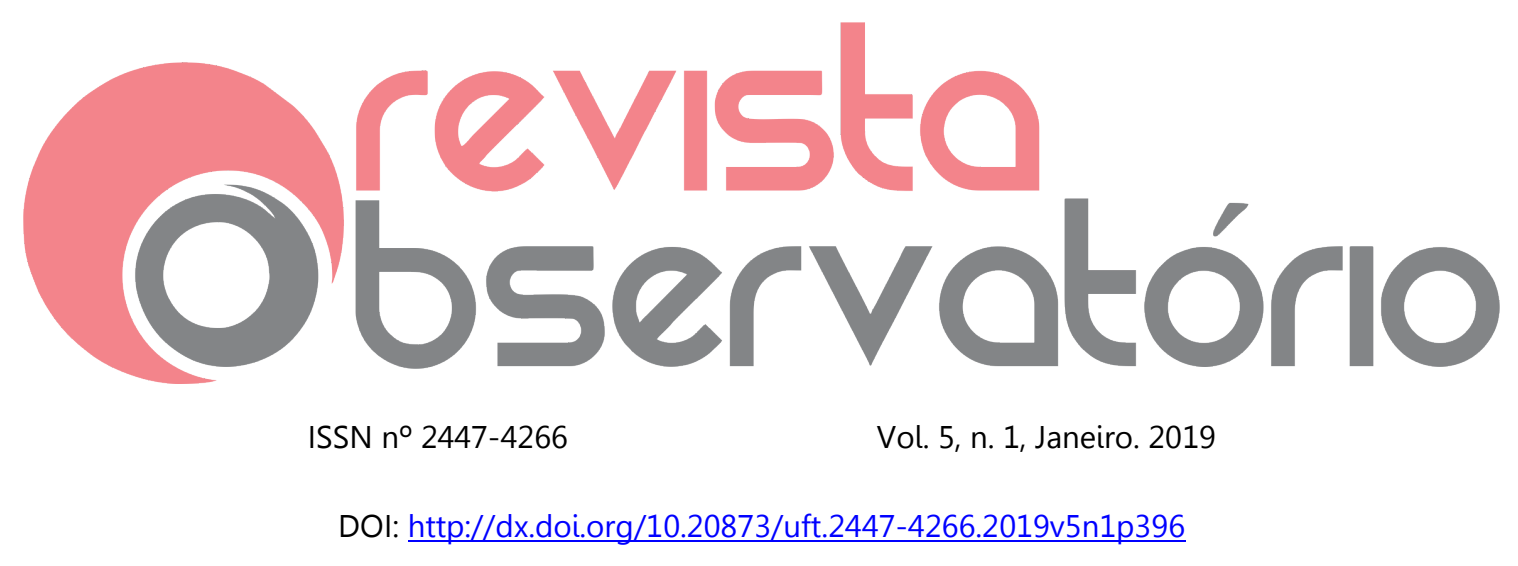

para o cidadão, que passou a ter amplo acesso aos dados públicos. De cumprimento obrigatório para todos os entes governamentais, essa Lei produz grandes impactos na gestão pública e exigirá, para sua efetiva implementação, a adoção de uma série de medidas.

Esses dados públicos disponibilizados na Internet precisam efetivamente proporcionar acesso às informações aos cidadãos. Os requisitos exigidos para os portais na internet precisam ser elaborados de forma a facilitar o acesso dos cidadãos às informações, prevendo a existência de ferramentas de busca e garantindo que as informações disponibilizadas possam ser amplamente utilizadas. Tendo em vista que há um processo nacional de modernização da Administração pública com foco na transparência e que as TICs, especialmente a Internet, desempenham um importante papel nesse processo. $O$ questionamento se dá em relação a real efetividade da utilização, pelos municípios do estado, da utilização da Internet para publicação das contas públicas e do acesso da população a essas informações. Diante desse contexto, formula-se a seguinte pergunta-problema: A Internet é efetivamente utilizada como um mecanismo de promoção da transparência e do acesso à Informação e Dados Públicos, pela população do Tocantins?

O objetivo geral deste estudo foi analisar a efetiva utilização da Internet como um mecanismo promotor da transparência e do acesso à Informação e Dados Públicos, pela população do Tocantins especificamente por meio dos Portais da Transparência dos municípios.

A proposta desta pesquisa foi entender a relação entre o Estado e a Sociedade Civil na Internet, este objeto foi escolhido não apenas pela importância dessa tecnologia em nossa sociedade atualmente, mas principalmente, por sua relevância no que se refere à promoção da 


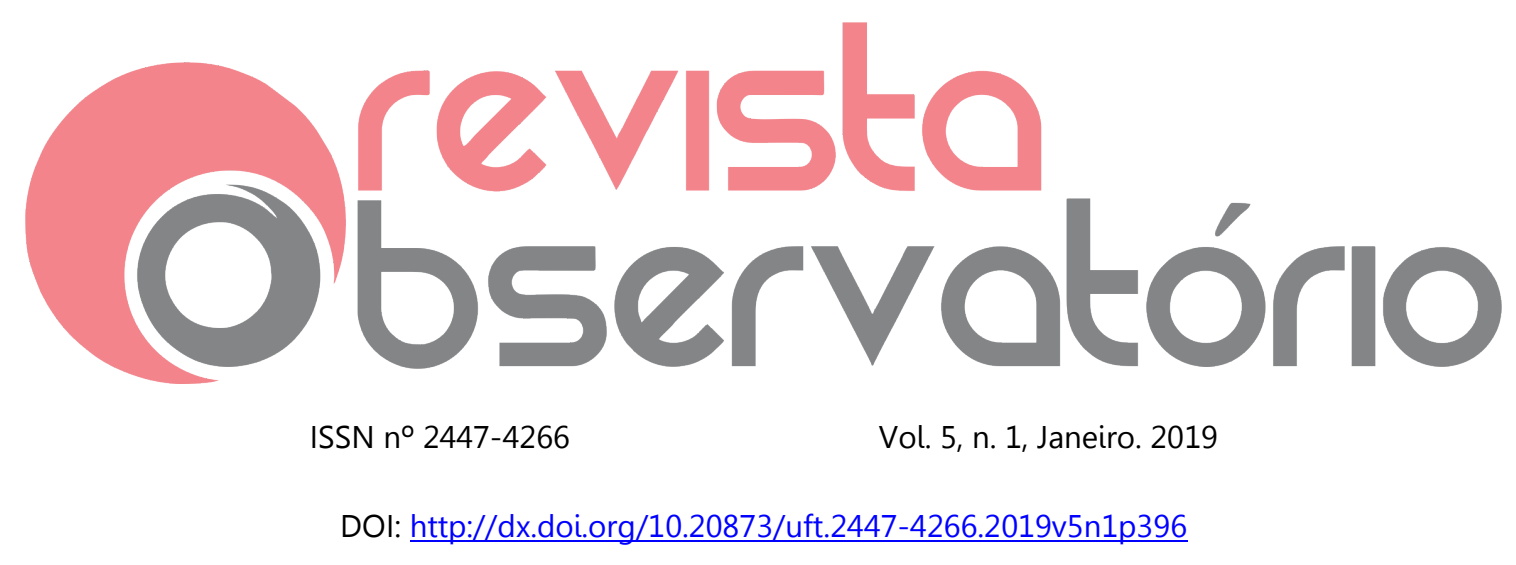

transparência e do acesso aos dados e informações públicas.

Dentre todas as complexidades que poderiam ser abordadas em torno desse tema, este trabalho foi delimitado em estudar a Internet apenas como um mecanismo de controle social, reduzindo seu campo no estado do Tocantins.

\section{PROCEDIMENTOS METODOLÓGICOS}

O Tocantins é composto por 139 municípios. Estes municípios foram considerados como sendo o universo da pesquisa e ranqueados de acordo com o Produto Interno Bruto - PIB, ordenando-os pelo volume econômico.

De acordo com Conduru (2010), a pesquisa foi explicativa, pois busca analisar o fenômeno e a partir daí entender os mesmo, diante dos contextos da relação da sociedade com o Estado, por meio da tecnologia.

A abordagem é quanti-qualitativa, pois a partir da coleta de informações diretas nos websites oficiais foram realizadas as devidas análises.

Para melhor compreensão da pesquisa caracterizou-se o estudo a partir de quatro critérios: quanto aos objetivos, quanto à abordagem, quanto às fontes e quanto aos procedimentos de coleta de dados.

Primeiro, quanto aos objetivos, no caso deste trabalho o tipo de pesquisa realizada para atingir o objetivo geral é a exploratória. A pesquisa exploratória visa proporcionar maior familiaridade com o problema no intuito de torná-lo explícito ou de construir hipóteses, envolve também a aplicação de instrumento com pessoas que tiveram contato com o objeto da pesquisa (GIL, 2000).

Segundo, quanto à abordagem, classificou-se essa pesquisa no método quali-quantitativo. De acordo com Rodrigues (1999, p. 57), a "leitura quantiqualitativa é aquela em que o investigador supera o preconceito para com os 


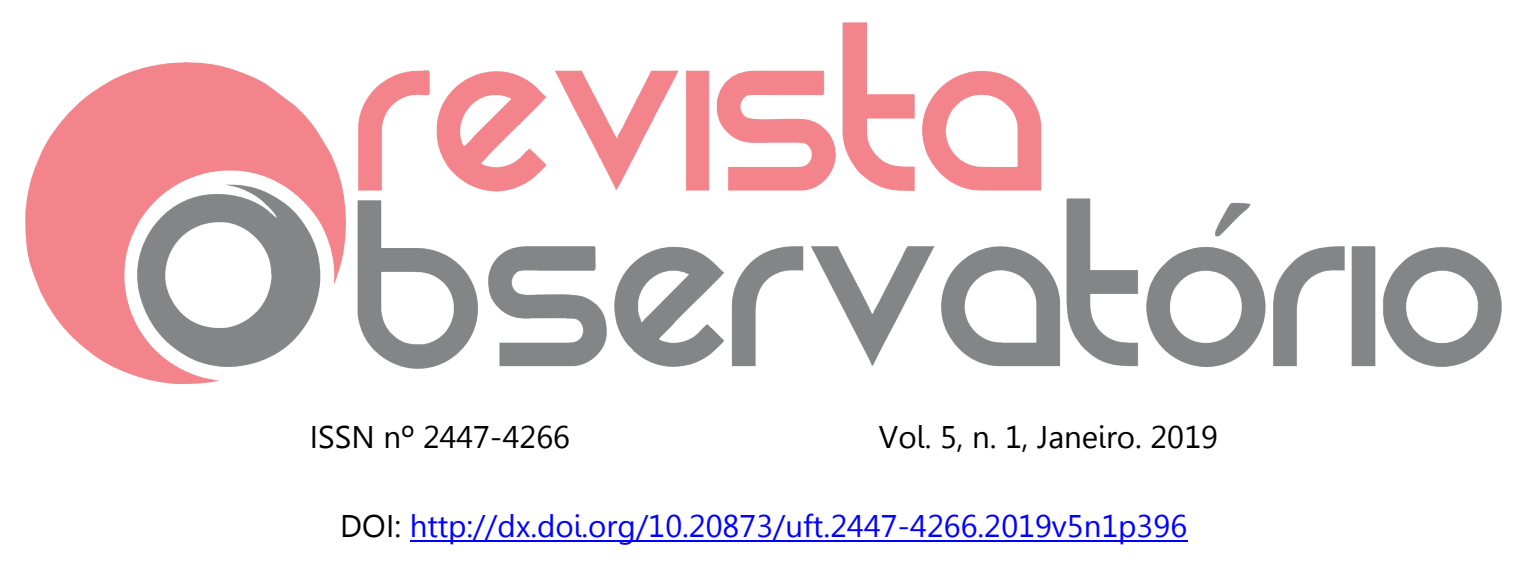

"números" e aprende a articulá-los às esferas subjetivas que os dados objetivos the oferecem".

Terceiro, quanto às fontes, definiu-se que na busca por um processo que ordenasse as contribuições científicas sobre o tema e que fornecesse subsídios para a solução do problema, realizar-se-ia uma pesquisa bibliográfica. Esse método objetiva recolher, selecionar, analisar e interpretar as contribuições teóricas já existentes sobre determinado assunto, como referências bibliográficas alusivas à temática em: sítios digitais, revistas e livros e de uma análise dos dados e conceitos sobre o assunto discutido (GIL, 2000).

Para se definir a amostra estudada, foram escolhidos os maiores municípios do estado do Tocantins. Investigará uma amostra representativa dos maiores municípios em relação ao número de habitantes, sendo definida a amostra de 23,3 municípios, arredondado para 25 municípios. Para se chegar a esta amostra, a média usada de amostragem da população foi calculada em população finita, utilizando-se o cálculo da amostra proposto por Martins e Theóphilo (2009).

Após a definição da amostra foram analisadas as prestações de contas públicas (na Internet) destes municípios, por meio de navegação orientada por uma estrutura de 32 aspectos de análise de acordo com os princípios da teoria da comunicação e o Manual de Acessibilidade do Governo Brasileiro (aplicável à navegação nos sites da gestão pública no Brasil).

Para a coleta de dados, foram realizadas navegações orientadas. Com isso, foi possível obter dados mais focados, além da criação de categorias descritivas. A criação de uma Ficha de Navegação Orientada facilitará a coleta dessas informações. 


\section{Obseristo \\ ISSN n² 2447-4266 \\ Vol. 5, n. 1, Janeiro. 2019 \\ DOI: http://dx.doi.org/10.20873/uft.2447-4266.2019v5n1p396}

\section{REFERENCIAL TEÓRICO}

\subsection{Transparência Pública}

A transparência na Administração Pública foi vista durante muito tempo como sinônimo de publicidade dos atos da gestão, porém, esse conceito é mais amplo e complexo, já que a transparência é um pressuposto para uma gestão democrática e menos vulnerável à corrupção e depende, essencialmente, do grau e da forma como se dá o acesso dos agentes econômicos e da sociedade organizada, e do próprio cidadão, à informação que sustenta os processos decisórios e garante o exercício dos direitos dos administrados. De forma didática, a Cartilha de Olho Vivo no Dinheiro Público (2009, p. 27) define: Transparência é quando sabemos onde, como e por que o dinheiro está sendo gasto. É quando as coisas são feitas às claras, sem mistérios, como devem ser feitas. A administração pública deve ser sempre transparente, porque não deve ter o que esconder do povo.

A transparência viabiliza o aumento do controle social pelos cidadãos, dificultando os vícios da Administração, tais como a corrupção, práticas clientelistas, entre outros; e permite a maior influência do cidadão na definição das políticas públicas. Ela tem que ser definida a partir de um conceito abrangente, assim, um governo transparente é aquele que dispõe as informações, as atualiza e cria facilidades para que o cidadão tenha acesso.

Transparência é ter condição de acesso a todas as informações sobre como o governo trabalha. A transparência quer dizer que a administração pública funciona de uma maneira aberta, baseada em princípios éticos, e é capaz de ser questionada a qualquer momento, em função da facilidade que têm os cidadãos e outros interessados em acessar as informações [...]. A transparência pode ser medida através das formas como são tomadas as decisões (democráticas, participativas ou centralizadas, autoritárias); pela eficácia dos canais de interação do governo com a comunidade - como, por exemplo 


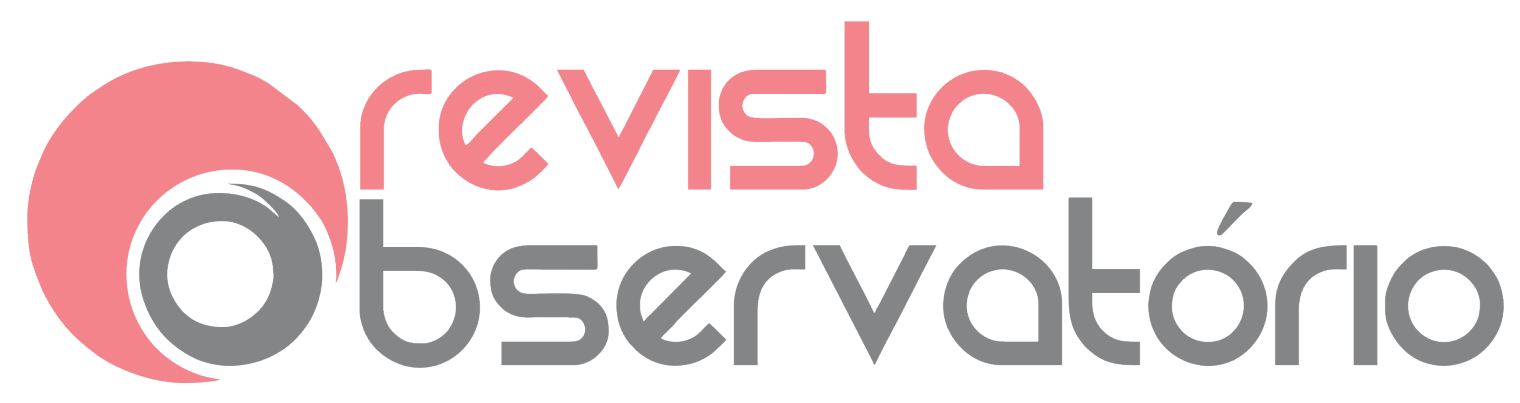

ISSN n² 2447-4266

Vol. 5, n. 1, Janeiro. 2019

DOI: http://dx.doi.org/10.20873/uft.2447-4266.2019v5n1p396

canais que possibilitem a participação dos cidadãos nas políticas públicas, questionando, sugerindo, monitorando, divulgando mobilizando etc. (TEIXEIRA, 2006, p.36).

Devemos salientar que para o governo e para sociedade a cultura de transparência, principalmente no que diz respeito às informações públicas, é muito importante, pois pode atuar como ferramenta fundamental na conferência das contas públicas e incentivam a educação política do cidadão, contudo a simples disponibilidade de dados das contas públicas não caracteriza a efetivação da transparência, para isso o acesso a essas informações deve ser livre, clara e, principalmente, fácil. Caso o contrário, para um Estado democrático que ocorre falta ou falhas nos mecanismos de transparência as penas são alarmantes. Para Loya, 2004 (apud Lopes, 2005, p. 40) "A falta de transparência é um foco potencial de abuso de poder e corrupção, outorgando discricionariedade a quem controla, restringe ou deliberadamente distorce $\mathrm{O}$ acesso à informação". A transparência implica, portanto, que a informação esteja disponível "sem travas" ou requisitos, que seja compreensiva ao incluir todos os elementos relevantes, e que seja confiável e de qualidade.

O Fundo Monetário Internacional tem defendido a adoção de métodos e práticas "transparentes" por parte de seus países membros, graças a sua experiência na área de gestão de finanças públicas e à universalidade de seus componentes, o FMI está bem situado para liderar a promoção de uma maior transparência fiscal. Para isso, vem produzindo e difundindo vários códigos e padrões de transparência e conduta, entre eles o Código de Boas Práticas para a Transparência Fiscal (2007), onde comenta que: A transparência fiscal representaria uma importante contribuição à causa da boa governança, pois promoveria um debate público mais bem informado sobre a concepção e os resultados das políticas fiscais ampliariam o controle sobre os governos no tocante à execução dessa política e, assim, aumentaria a credibilidade e a 


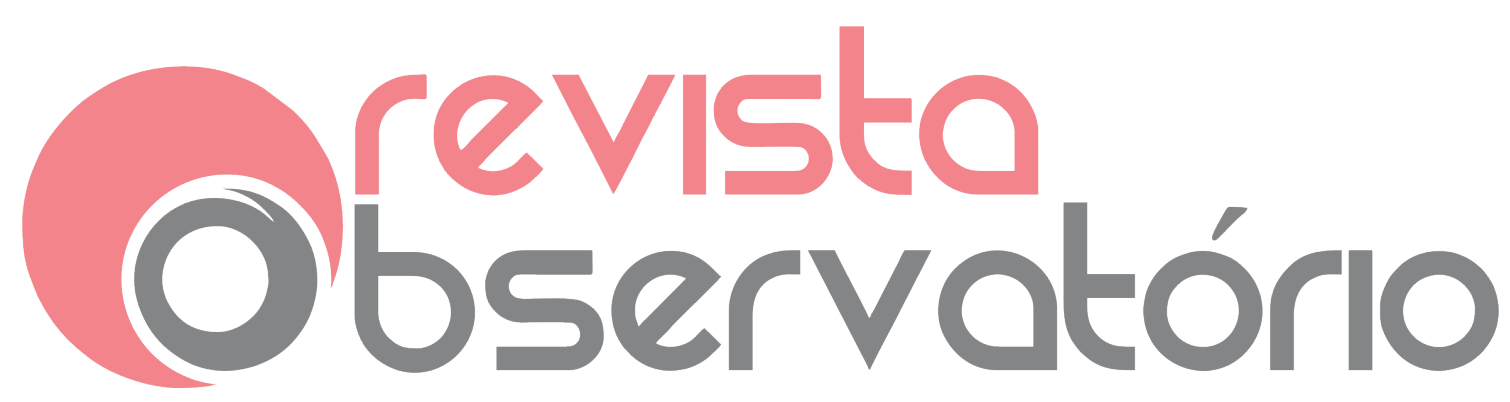

ISSN n² 2447-4266

Vol. 5, n. 1, Janeiro. 2019

DOI: http://dx.doi.org/10.20873/uft.2447-4266.2019v5n1p396

compreensão das políticas e opções macroeconômicas por parte do público. Num ambiente de globalização, a transparência reveste-se de considerável importância para alcançar a estabilidade macroeconômica e o crescimento de alta qualidade.

Em termos de transparência a LRF - Lei de Responsabilidade Fiscal - é um divisor de águas na história das finanças públicas no Brasil, ela foi elaborada para primar pelo equilíbrio entre receitas e despesas e pela transparência fiscal.

A LRF apresenta alguns instrumentos de transparência, conforme podemos verificar no art. 48 :

\begin{abstract}
São instrumentos de transparência da gestão fiscal, aos quais será dada ampla divulgação, inclusive em meios eletrônicos de acesso público: os planos, orçamentos e leis de diretrizes orçamentárias; as prestações de contas e o respectivo parecer prévio; o Relatório Resumido da Execução Orçamentária e o Relatório de Gestão Fiscal; e as versões simplificadas desses documentos.

Parágrafo único. A transparência será assegurada também mediante: $\S 2^{\circ}$ - Liberação ao pleno conhecimento e acompanhamento da sociedade, em tempo real, de informações pormenorizadas sobre a execução orçamentária e financeira, em meios eletrônicos de acesso público.
\end{abstract}

Fica claro, que entre as finalidades da transparência da gestão fiscal, há a intenção de fomentar ao Estado um arcabouço legal necessário para institucionalizar, no Brasil, um sistema de informação conforme os padrões e demandas internacionais. Traduzindo o princípio da transparência, este sistema busca franquear ao público acesso a informações relativas à política fiscal, divulgando-as segundo padrões de confiabilidade, abrangência e comparabilidade (CRUZ, 2006).

Quanto aos mecanismos de divulgação das informações ao público, podemos observar os métodos tradicionais, como publicação de relatórios e demonstrações, como também, os meios mais modernos como, por exemplo, as mídias eletrônicas, que são uma tendência atual, reflexo do aumento cada 


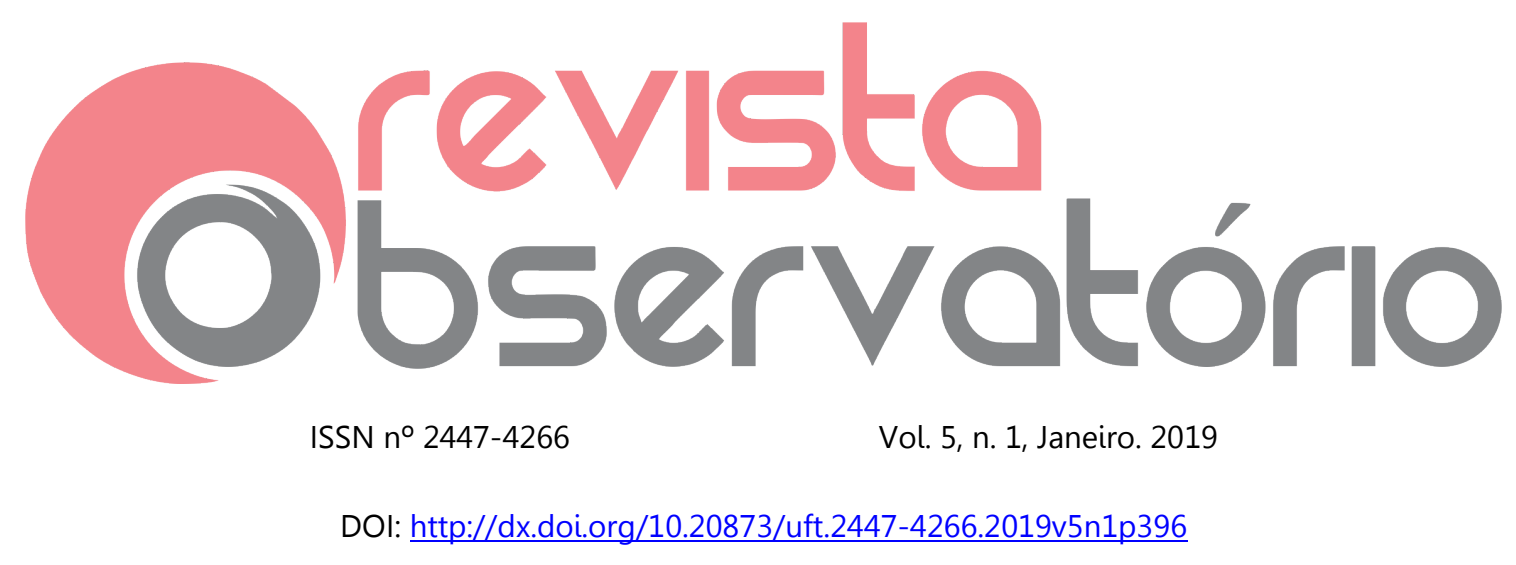

vez maior de pessoas acessando a rede mundial de computadores, popularizando, dessa forma, as informações sobre a administração pública.

Surge, então, a necessidade de serem instrumentalizados mecanismos que assegurem a fidedignidade destas informações divulgadas, além de se criarem padrões de versões simplificadas dos documentos, com o uso de macro números, indicadores, etc., visando facilitar o entendimento da população leiga (CRUZ, 2006).

Nesse contexto, visando atender as legislações e códigos de conduta, foram criados os portais da transparência que são sites que disponibilizam informações sobre os gastos públicos, um instrumento legítimo de prevenção à corrupção e de controle de recursos.

\subsection{Controle Social}

O dicionário enciclopédico de Administração (2003, p. 315) diz que: "O conceito de controle tem significado e utilização tão grandes em todos os campos de estudo, que se torna quase impossível uma definição". Já no dicionário Houaiss da língua portuguesa, o significado da palavra controle tem um sentido de domínio e, talvez por isso, o controle é muitas vezes enxergado como um procedimento inconveniente, afinal ninguém gosta de ser controlado. Essa expressão está muito associada à fiscalização, ao ato de evidenciar, caso ocorra, algum desvio ou irregularidade.

Porém, dentro da ciência da Administração o controle é visto como uma função administrativa que visa: "Assegurar que os resultados do que foi planejado, organizado e dirigido se ajustaram, tanto quanto possível, aos objetivos previamente estabelecidos. A essência do controle reside na verificação se atividade controlada está ou não alcançando os resultados 


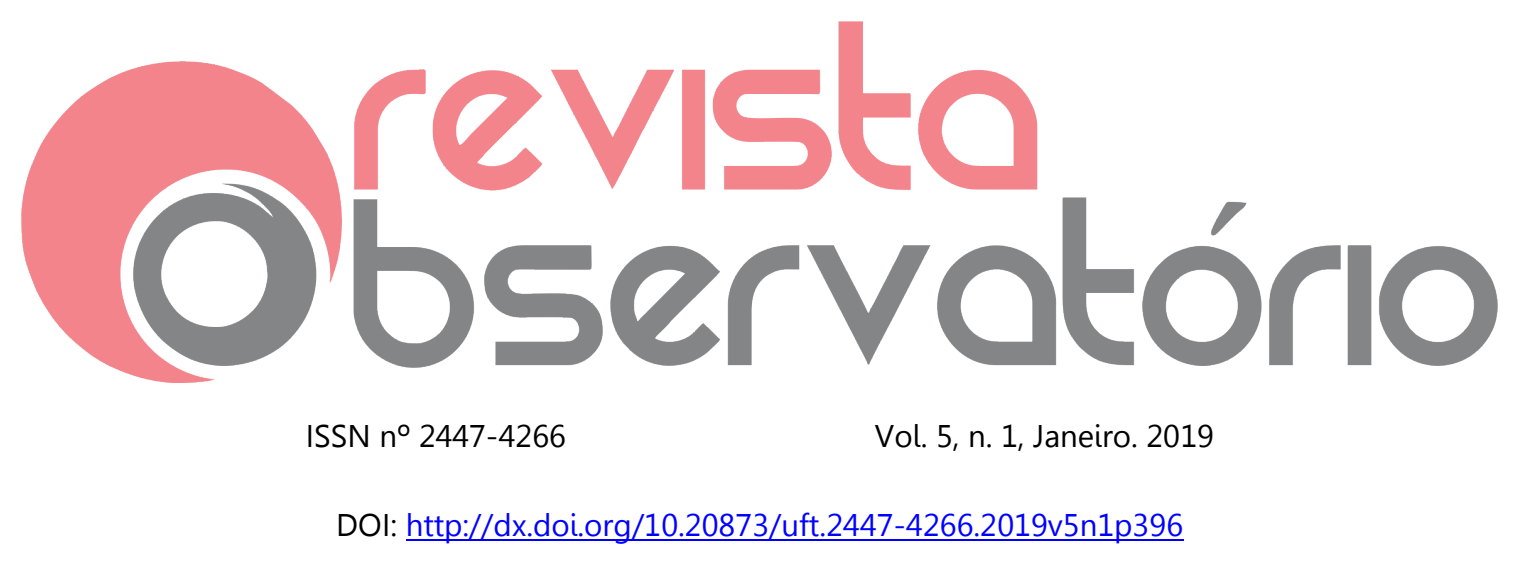

desejados" (CHIAVENATO, 2003, p. 176).

Nota-se, assim, que o controle pode ser também um meio pelo qual se consegue detectar erros e providenciar ações corretivas, está associado à maneira com que as pessoas que compõe a organização executam suas atividades, para os processos funcionem no tempo e da forma correta.

Na Administração Pública, o ato de controlar possui significado similar, na medida em que pressupõe examinar se a atividade governamental atendeu à finalidade pública, à legislação e aos princípios básicos aplicáveis ao setor público. O Manual para os Agentes Municipais da CGU (2005, p.16) destaca a importância do controle na gestão pública: "O controle é uma das funções clássicas da administração de qualquer entidade, seja pública ou privada, sendo precedido pelas atividades administrativas de planejamento, organização e coordenação". Na administração pública, esta função é mais abrangente e necessária em virtude do dever de prestação de contas a que todo ente estatal está submetido.

A forma de controle que é executada no âmbito da gestão pública apresenta um aspecto interessante, pois, verifica-se principalmente o que concerne aos gastos públicos, não tem preocupação apenas na questão dos processos como é na administração privada.

O Controle na Gestão Pública pode ser entendido, também, como o poder de fiscalização e correção que a Administração Pública (em sentido amplo) exerce sobre a sua própria atuação, sob os aspectos de legalidade e mérito, por iniciativa própria ou mediante provocação (DI PIETRO, 1997).

A Constituição da República, ao regulamentar o controle dos gastos públicos, estabeleceu, em seus artigos $70^{5}$ a 74 , mormente, dois tipos de

\footnotetext{
${ }^{5}$ Art. 70. A fiscalização contábil, financeira, orçamentária, operacional e patrimonial da União e das entidades da administração direta e indireta, quanto à legalidade, legitimidade, economicidade, aplicação
} 


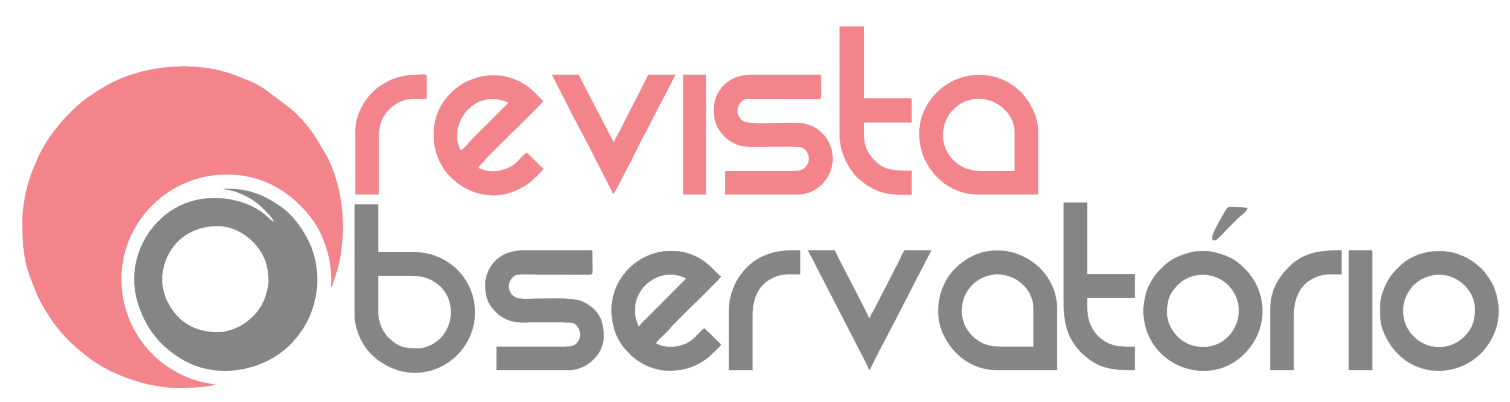

ISSN n² 2447-4266

Vol. 5, n. 1, Janeiro. 2019

DOI: http://dx.doi.org/10.20873/uft.2447-4266.2019v5n1p396

controle: o externo e o interno.

O controle externo é aquele exercido pelo Poder Legislativo, auxiliado pelos Tribunais de conta da União, dos Estados e dos Municípios, esses tribunais especializados em contas públicas auxiliam os parlamentares na fiscalização financeira, patrimonial, contábil e operacional, por meio de elaboração de relatórios e pareceres que fundamentam o julgamento político das contas da gestão, o auxílio dado por essas cortes é essencial, se considerarmos o quão complexa é a arrecadação e a aplicação dos recursos públicos.

Já o controle interno é assim chamado por ser exercido pelos próprios Poderes (Legislativo, Executivo e Judiciário) dentro deles mesmos, ou seja, essas entidades mantêm órgãos com a finalidade precípua de controlar seus próprios gastos.

\section{A Constituição Federal disciplina sobre o assunto:}

Art. 74. Os Poderes Legislativo, Executivo e Judiciário manterão, de forma integrada, sistema de controle interno com a finalidade de:

I - avaliar o cumprimento das metas previstas no plano plurianual, a execução dos programas de governo e dos orçamentos da União;

II - comprovar a legalidade e avaliar os resultados, quanto à eficácia e eficiência, da gestão orçamentária, financeira e patrimonial nos órgãos e entidades da administração federal, bem como da aplicação de recursos públicos por entidades de direito privado;

III - exercer o controle das operações de crédito, avais e garantias, bem como dos direitos e haveres da União;

IV - apoiar o controle externo no exercício de sua missão institucional $\S 1.0$ Os responsáveis pelo controle interno, ao tomarem conhecimento de qualquer irregularidade ou ilegalidade, dela darão ciência ao Tribunal de Contas da União, sob pena de responsabilidade solidária.

§ 2.0 Qualquer cidadão, partido político, associação ou sindicato é parte legítima para, na forma da lei, denunciar irregularidades ou ilegalidades perante o Tribunal de Contas da União

das subvenções e renúncia de receitas, será exercida pelo Congresso Nacional, mediante controle externo, e pelo sistema de controle interno de cada Poder.

Parágrafo único. Prestará contas qualquer pessoa física ou entidade pública que utilize, arrecade, guarde, gerencie ou administre dinheiros, bens e valores públicos ou pelos quais a União responda, ou que, em nome desta, assuma obrigações de natureza pecuniária. (CF, 1988) 


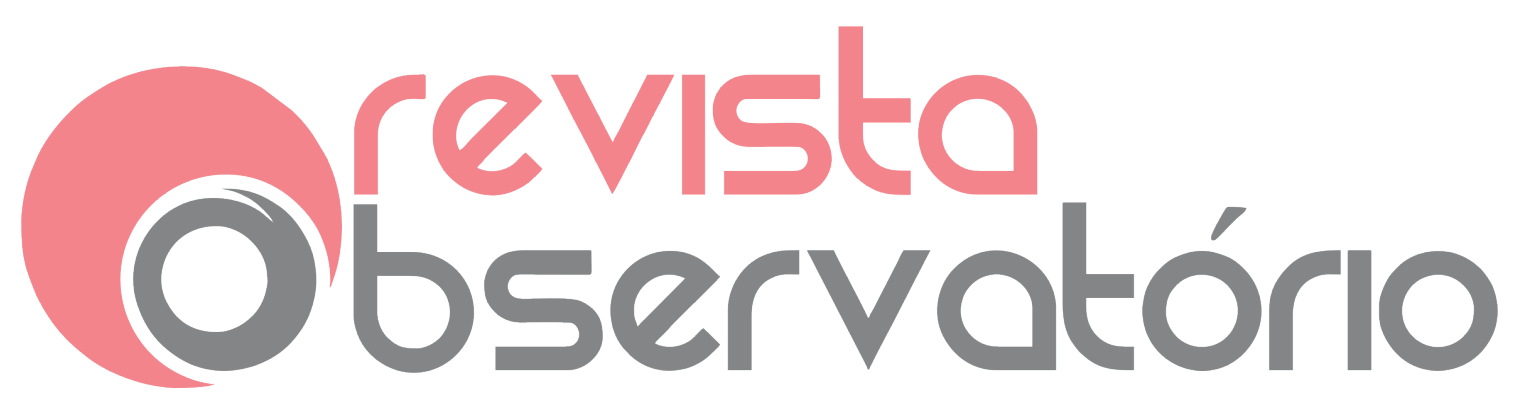

ISSN n² 2447-4266

Vol. 5, n. 1, Janeiro. 2019

DOI: http://dx.doi.org/10.20873/uft.2447-4266.2019v5n1p396

(CF, 1989).

Para avançar a pauta sobre controle é imprescindível compreender que esses diversos dispositivos constitucionais, buscam garantir que a gestão atue de acordo os princípios explícitos da nossa Carta Magna que são: Legalidade ${ }^{6}$, Moralidade ${ }^{7}$, Impessoalidade ${ }^{8}$, Publicidade ${ }^{9}$ e Eficiência ${ }^{10}$.

Quando une-se o vocábulo Controle com o termo "social", dá-se um novo sentido ao primeiro, assim o Controle social apresenta um aspecto fundamental de significado, que é a fiscalização que emana da sociedade, que se origina do povo para o povo. A evolução nas formas de interação ou associação entre os setores que compõem a sociedade exigiu a modificação dos instrumentos legais para que houvesse a expansão dessa participação do cidadão.

Da mesma forma, pode-se considerar que a descentralização das atribuições do Estado impôs a necessidade de uma participação cada vez maior da sociedade no controle da Administração. Isso é o que tem sido denominado controle social (SILVA, 2009).

Para Bobbio (1998, p.283):

Por Controle social se entende o conjunto de meios de intervenção, quer positivos quer negativos, acionados por cada sociedade ou grupo social a fim de induzir os próprios membros a se conformarem às normas que a caracterizam, de impedir e desestimular os comportamentos contrários às mencionadas normas, de restabelecer condições de conformação, também em relação a uma mudança do sistema normativo.

\footnotetext{
${ }^{6}$ Legalidade: Segundo o qual ao administrador somente é dado realizar o quanto previsto na lei.

7 Moralidade: Que encerra a necessidade de toda atividade administrativa, bem assim de os atos administrativos atenderem a um só tempo à lei, à moral, à equidade, aos deveres de uma boa administração.

${ }^{8}$ Impessoalidade: Porquanto a atuação deve voltar-se ao atendimento impessoal, geral, não sendo a atuação atribuída ao agente público, mas à entidade estatal.

${ }^{9}$ Publicidade: A obrigatória divulgação de informações de todos os atos da Administração.

10 Eficiência: Que impõe a necessidade de adoção, pelo administrador, de critérios técnicos, ou profissionais, que assegurem o melhor resultado possível, abolindo-se qualquer prática de forma amadorística. (ROSA, 2009)
} 


\section{Observisto \\ ISSN n² 2447-4266 \\ Vol. 5, n. 1, Janeiro. 2019 \\ DOI: http://dx.doi.org/10.20873/uft.2447-4266.2019v5n1p396}

A ideia de controle social foi apresentada na sociologia americana de cunho funcionalista na década de 1920 e estava associada a estudos de atitudes socialmente indesejáveis, pressupunha padrões de comportamento que deveriam ser respeitados pelos membros da própria sociedade. O controle social referente aos processos de redemocratização do Estado é recente, como mostra (Di Pietro, 1997) em seu quadro que resume a transformação histórica do papel do Estado em relação à concepção relativa a cidadania.

Quadro 1: Sobre o papel do Estado e os direitos da cidadania

\begin{tabular}{|c|c|c|c|}
\hline & $\begin{array}{l}\text { Estado de direito liberal } \\
\text { (Brasil - até 1930) }\end{array}$ & $\begin{array}{l}\text { Estado de direito social } \\
\text { (Brasil - 1930-90) }\end{array}$ & $\begin{array}{l}\text { Estado democrático } \\
\text { (Brasil } 1990 \text { - Atual) }\end{array}$ \\
\hline $\begin{array}{l}\text { Direitos da } \\
\text { cidadania }\end{array}$ & $\begin{array}{l}\text { Liberdade e direitos } \\
\text { individuais. }\end{array}$ & \begin{tabular}{|c|} 
Socialização e \\
preocupação com o bem \\
comum \\
Diretos individuais ao lado \\
dos direitos econômicos e \\
sociais.
\end{tabular} & $\begin{array}{l}\text { Participação popular no } \\
\text { processo politico e no } \\
\text { controle das atividades } \\
\text { governamentais }\end{array}$ \\
\hline
\end{tabular}

Fonte: (Di Pietro, 1997)

Nesse contexto de transformação do papel do Estado e da sua relação com a sociedade que pode ser vista a retomada da discussão acerca do controle e participação social, que remete ao desenvolvimento da cidadania e a construção de um ambiente democrático. O controle social passa a ser visto, então, como uma conquista da sociedade civil, um instrumento de expressão da democracia. Cunha (2003, p. 03), diz que: "Com os processos de democratização e diminuição do papel do Estado na economia e vida social, o controle social assume uma nova dimensão". Ele é visto como a capacidade que tem a sociedade organizada de intervir nas políticas públicas, interagindo com o Estado na definição de prioridades e na elaboração dos planos de ação do município, estado ou do governo federal (CUNHA, 2003). 


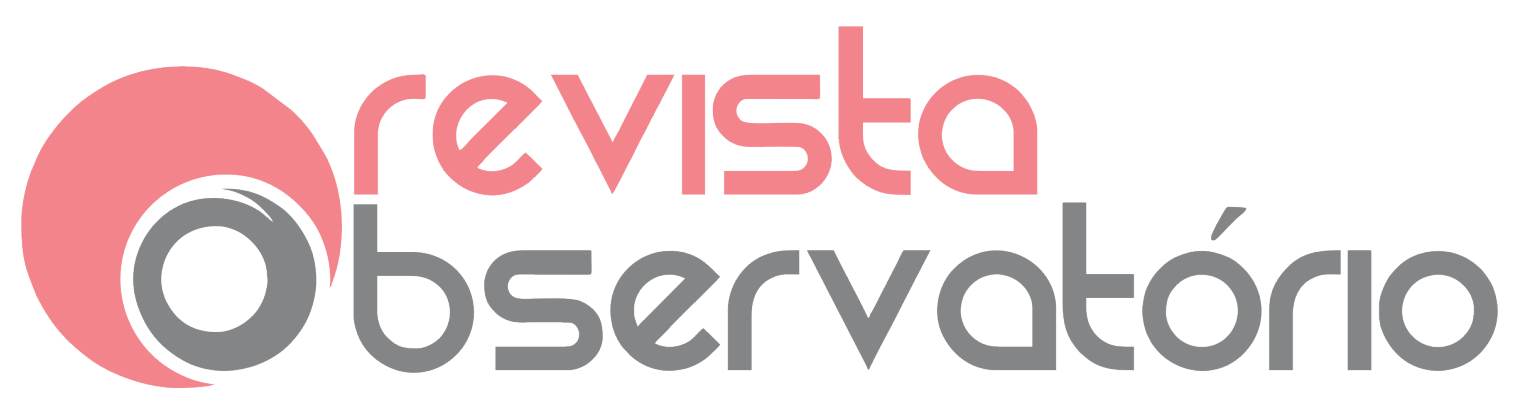

ISSN n² 2447-4266

Vol. 5, n. 1, Janeiro. 2019

DOI: http://dx.doi.org/10.20873/uft.2447-4266.2019v5n1p396

O controle social das organizações públicas pode ocorrer de duas maneiras: de baixo para cima, quando a sociedade se organiza politicamente para controlar ou influenciar instituições sobre as quais não se tem poder formal; ou de cima para baixo, quando é exercido formalmente por conselhos de instituições públicas não-estatais (BRESSER-PEREIRA, 2002).

Para que esse controle funcione adequadamente é necessário que ele se sustente numa sociedade forte, organizada e ativa, que atue em conjunto com as formas tradicionais internas e/ou externas de controle, como a exercida pelo Tribunal de Contas da União. Complementando a Secretaria de Prevenção da Corrupção e Informações Estratégicas afirma:

Tendo em vista a complexidade das estruturas político-sociais de um
país e do próprio fenômeno da corrupção, o controle da
Administração Pública não se deve restringir ao controle institucional.
É fundamental para toda a coletividade que ocorra a participação dos
cidadãos e da sociedade organizada no controle do gasto público,
monitorando permanentemente as ações governamentais e exigindo
o uso adequado dos recursos arrecadados. A isto se denomina
"controle social" (CGU, 2008, pág. 16).

Os mecanismos de controle social são tão importantes que foram garantidos na Constituição no inciso $\mathrm{LXXIII11}$ do art.5 $5^{\circ}$, esse fragmento mostra que o cidadão pode, a qualquer tempo, influir na gestão pública, não se limitando à participação eleitoral. Assim, o foco do constituinte foi de aproximar o governo e o cidadão com o objetivo de atender os anseios da sociedade e contribuir na fiscalização nas contas da administração pública.

A Constituição de 1988 foi um divisor de águas em nossa história da cidadania, pois ela inaugura o conceito de cidadania ativa, dando partida no processo de combate ao clientelismo, o patrimonialismo e as impunidades

\footnotetext{
${ }^{11}$ Qualquer cidadão é parte legítima para propor ação popular que vise anular ato lesivo ao patrimônio público ou de entidade de que o Estado participe, à moralidade administrativa, ao meio ambiente e ao patrimônio histórico e cultural, ficando o autor, salvo comprovada má-fé, isento de custas judiciais e do ônus da sucumbência. (CF, 1989)
} 


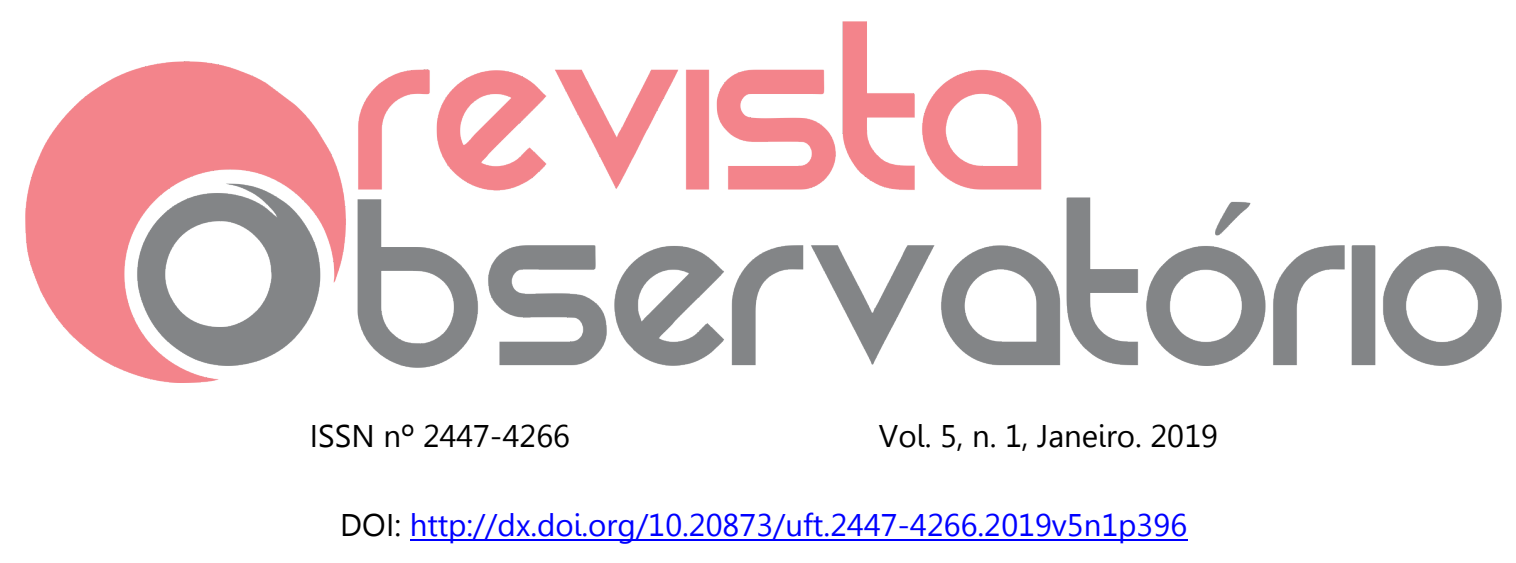

(LOPES, 2008).

Para o Brasil, estabelecer um controle social forte e atuante é fundamental, em razão da sua extensão territorial e da descentralização geográfica os órgãos públicos integrantes dos diversos níveis federativos - União, estados, Distrito Federal e municípios. Por isso, a fiscalização da aplicação dos recursos públicos precisa ser feita com o apoio da sociedade. De acordo com a Cartilha de Olho Vivo no Dinheiro Público (2010) O controle social é um complemento indispensável ao controle institucional realizado pelos órgãos que fiscalizam os recursos públicos. Essa participação é importante porque contribui para a boa e correta aplicação dos recursos públicos, fazendo com que as necessidades da sociedade sejam atendidas de forma eficiente.

A produção intelectual recente sobre essa temática converge no sentido de identificar o controle social como um termo referente à possibilidade de atuação de grupos sociais por meio de qualquer uma das vias de participação democrática no controle das ações do Estado e dos gestores públicos.

Partindo dessa percepção generalista de democracia representativa, podemos entender que a dinâmica do processo de planejamento, execução e controle do Estado poderia ser visualizada da seguinte forma de sequência e etapas: demanda da sociedade, proposta do Gestor público, designação, planejamento (Plano Plurianual, Lei de Diretrizes Orçamentárias e Lei Orçamentária Anual), execução, controle e atuação por meio das vias democráticas. Como é demonstrado no Diagrama a seguir: 


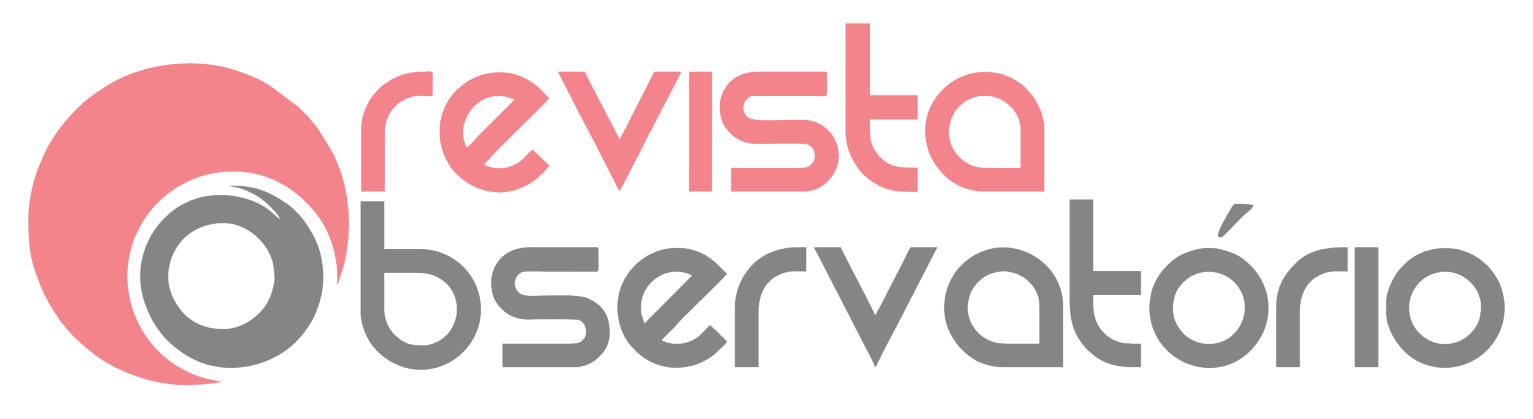

ISSN n² 2447-4266

Vol. 5, n. 1, Janeiro. 2019

DOI: http://dx.doi.org/10.20873/uft.2447-4266.2019v5n1p396

Figura 4: Diagrama da dinâmica do Controle social.

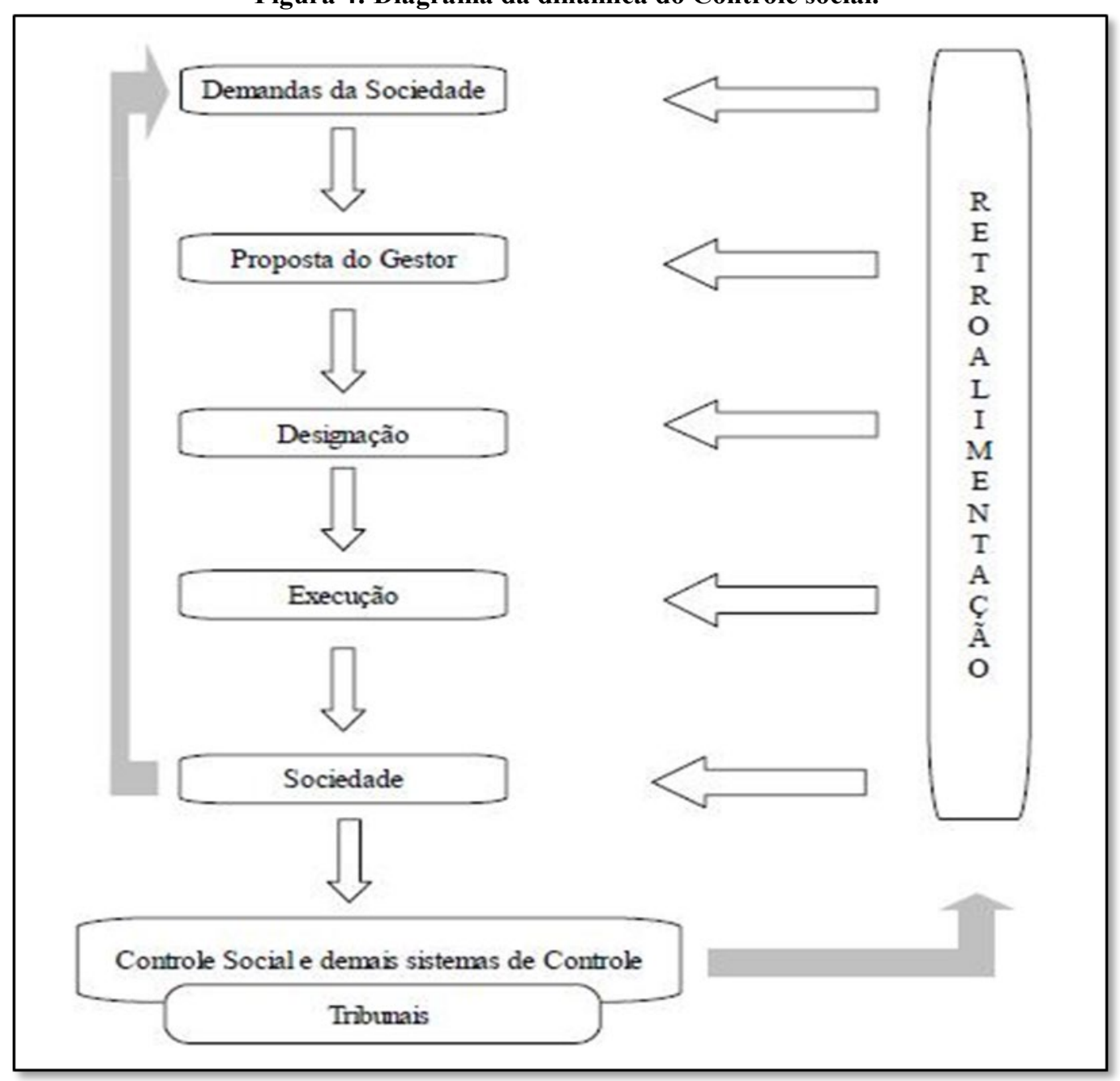

FONTE: (ROSA, 2009)

Pode-se observar que nessa dinâmica a sociedade passa a funcionar como um agente passivo e ativo do processo, aparecendo com a função de alimentação do ciclo com as informações que permitem o ajuste, a correção e os novos planejamentos, e como agente de fiscalização para identificar falhas durante o processo. Neste estudo, nos interessa compreender os mecanismos de monitoração da sociedade partindo desse cenário amplo e complexo, para um contexto específico que aborda o controle social que é fomentado através 


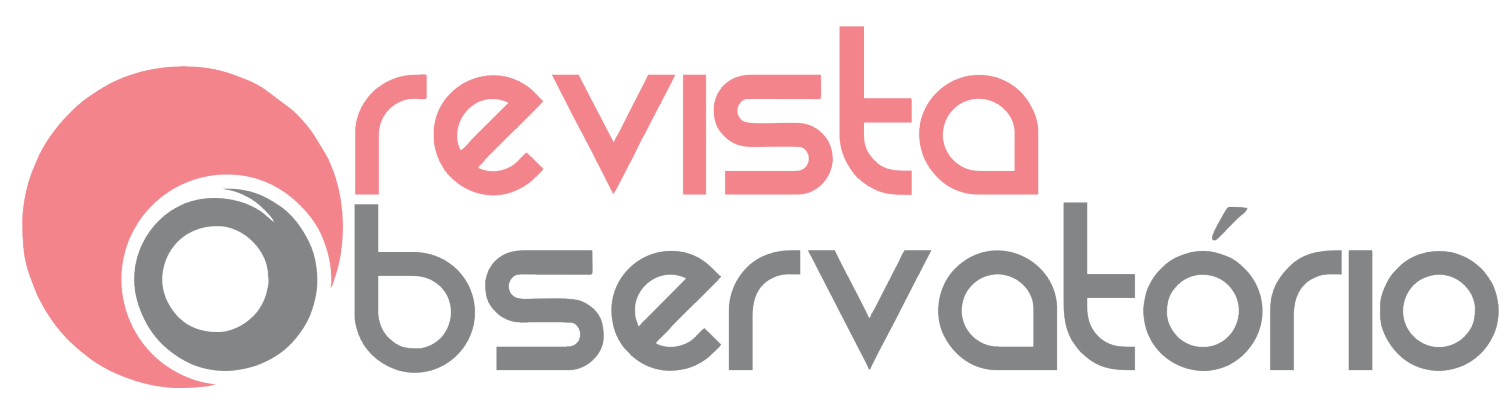

ISSN n² 2447-4266

Vol. 5, n. 1, Janeiro. 2019

DOI: http://dx.doi.org/10.20873/uft.2447-4266.2019v5n1p396

do uso eficiente da informação pública na Internet.

Para que o controle social aconteça dentro da organização pública foi criado o accountability ${ }^{12}$, que é a obrigação que as organizações e pessoas têm de prestar contas dos resultados obtidos, em função das responsabilidades que decorrem de uma delegação de poder, está é uma ferramenta básica no processo que integra a sociedade no controle efetivo dos gastos públicos e responsabilização dos gestores (MANNARINO, 2006).

Com esse instrumento, os cidadãos ganham a oportunidade de observar os trabalhos realizados pela administração estatal e analisar se os governantes estão agindo em função do interesse da coletividade. Vale frisar que esta observação está apoiada em quatro fundamentos: relações éticas, conformidade, transparência e prestação responsável das contas (MATIASPEREIRA, 2009).

Pode-se afirmar que esses fundamentos são essenciais para que a sociedade garanta o controle sobre os atos gerenciais, a fim de progredir no processo de desenvolvimento socioeconômico. Assim como afirma Neto (2002, p.321):

A sociedade pode e deve ser chamada a participar e assumir responsabilidade compartilhada pela gestão pública, através de diversos mecanismos de diálogo e interação do Estado - Sociedade, no Brasil tem se utilizado com frequência o "orçamento participativo". No entanto, este processo apresenta variadas formas de aplicação prática.

Cabe destacar então, que essas outras formas que ficam subentendidas no texto podem ser instrumentos como, por exemplo, a Internet que viabiliza o

${ }^{12} \mathrm{O}$ termo accountability pode ser aceito como um conjunto de mecanismos e procedimentos que induzem os dirigentes governamentais a prestar contas dos resultados de suas ações à sociedade, garantindo-se dessa forma maior nível de transparência e a exposição pública das políticas públicas. Quanto maior a possibilidade de os cidadãos poderem discernir se os governantes estão agindo em função do interesse da coletividade e sancioná-lo apropriadamente, mais accountable é o governo. Trata-se de um conceito fortemente relacionado ao universo político anglo-saxão. (Matias-Pereira, 2009, p. 70) 


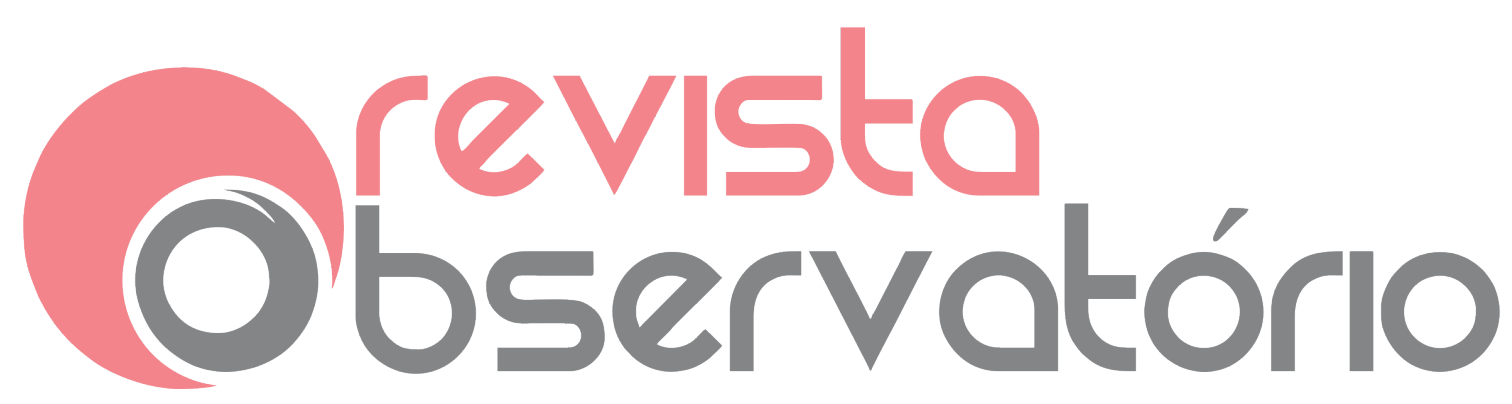

ISSN n² 2447-4266

Vol. 5, n. 1, Janeiro. 2019

DOI: http://dx.doi.org/10.20873/uft.2447-4266.2019v5n1p396

controle social por meio do acesso às informações públicas, possibilitando o acompanhamento da alocação de recursos públicos, o combate a corrupção e a avaliação das políticas públicas.

\section{APRESENTAÇÃO E ANÁLISE DOS DADOS}

Nesta etapa, descrevem-se os dados coletados, bem como a análise dos resultados encontrados. Como já descrito nos procedimentos metodológicos, foi definido como objeto de estudo os 25 maiores municípios do estado do Tocantins, considerando o cálculo da amostra proposto por Martins e Theóphilo (2009) e as informações dos municípios publicadas pelo IBGE (2010) e Portal da Transparência (2016). A Tabela 1 apresenta os 25 municípios definidos para esta pesquisa, acrescidos de algumas informações demográficas.

Tabela 1 - Dados demográficos

Fonte: IBGE (2010). Portal da Transparência (2016).

Nota: População, PIB e IDH 2010. Renda Per Capta 2010 - Correção 2014. Repasses Federais 2016. 


\section{Observisto}

ISSN n² 2447-4266

Vol. 5, n. 1, Janeiro. 2019

DOI: http://dx.doi.org/10.20873/uft.2447-4266.2019v5n1p396

Fonte: Da pesquisa (2017)

\begin{tabular}{l|l|l|l|l|l}
\hline MUNICIPIO & PIB & População & PIB per capta & IDH & $\begin{array}{l}\text { Repasses } \\
\text { Federais }\end{array}$ \\
& & & & & \\
\hline Palmas & & & & & \\
\hline Araguaína & 5.094 .771 & 228.332 & $24.657,41$ & 0,788 & $448.501 .474,33$ \\
\hline Gurupi & 2.547 .013 & 150.484 & $18.265,69$ & 0,752 & $199.862 .678,30$ \\
\hline Porto Nacional & 1.443 .665 & 76.755 & $20.337,85$ & 0,759 & $77.242 .848,17$ \\
\hline Paraíso do Tocantins & 839.679 & 49.146 & $21.618,66$ & 0,740 & $73.191 .754,81$ \\
\hline Peixe & 713.362 & 44.417 & $19.139,67$ & 0,764 & $47.221 .270,24$ \\
\hline Colinas do Tocantins & 569.822 & 10.384 & $34.721,47$ & 0,674 & $18.864 .907,15$ \\
\hline Pedro Afonso & 416.969 & 30.838 & $15.540,06$ & 0,701 & $45.534 .731,69$ \\
\hline Guaraí & 375.407 & 11.539 & $55.239,90$ & 0,732 & $17.533 .528,50$ \\
\hline Miracema do To & 369.488 & 23.200 & $18.668,74$ & 0,741 & $29.092 .062,92$ \\
\hline Formoso do Araguaia & 350.474 & 20.684 & $19.740,61$ & 0,684 & $27.006 .767,18$ \\
\hline Lagoa da Confusão & 316.360 & 18.427 & $17.304,30$ & 0,670 & $26.804 .895,40$ \\
\hline Dianópolis & 281.019 & 10.210 & $36.542,24$ & 0,627 & $16.866 .247,53$ \\
\hline Araguatins & 271.152 & 31.312 & $17.620,68$ & 0,701 & $27.728 .705,70$ \\
\hline Campos Lindos & 261.317 & 8.139 & $8.968,35$ & 0,631 & $43.086 .039,61$ \\
\hline Xambioá & 259.732 & 11.484 & $27.367,88$ & 0,544 & $16.974 .394,87$ \\
\hline Paranã & 220.360 & 10.338 & $16.325,80$ & 0,595 & $19.871 .092,51$ \\
\hline Tocantinópolis & 195.837 & 22.619 & $9.760,88$ & 0,681 & $32.081 .325,54$ \\
\hline Alvorada & 189.564 & 8.374 & $27.341,52$ & 0,708 & $12.228 .341,58$ \\
\hline Nova Olinda & 183.272 & 10.686 & $19.683,57$ & 0,631 & $20.221 .964,94$ \\
\hline Taguatinga & 177.452 & 15.051 & $13.031,16$ & 0,634 & $23.897 .011,36$ \\
\hline Augustinópolis & 158.006 & 15.950 & $14.684,60$ & 0,657 & $26.291 .740,69$ \\
\hline Arraias & 142.221 & 10.645 & $12.712,37$ & 0,651 & $16.862 .334,81$ \\
\hline Miranorte & 134.522 & 12.623 & $12.709,76$ & 0,662 & $21.553 .633,06$ \\
\hline Araguaçu & 117.061 & 8.786 & $15,679,69$ & 0,675 & $13.511 .906,82$ \\
\hline & & & & & \\
\hline
\end{tabular}

Tabela 2: Observação geral

\begin{tabular}{l|l|l}
\hline Relatório & Possuem & Não possuem \\
\hline
\end{tabular}




\section{Observatório}

ISSN n² 2447-4266

Vol. 5, n. 1, Janeiro. 2019

DOI: http://dx.doi.org/10.20873/uft.2447-4266.2019v5n1p396

\begin{tabular}{l|c|c}
\hline RREO e RGF & $12-60 \%$ & $8-40 \%$ \\
\hline Sites não avaliados & \multicolumn{2}{|c|}{$5-20 \%$} \\
\hline
\end{tabular}

Fonte: Da pesquisa (2017)

Pelo menos cinco sites e/ou portais da transparência dos respectivos municípios não foram avaliados, uma vez que não estavam disponíveis em pelo menos três navegações. Os demais sites foram avaliados normalmente, porém 40\% deles não possuem link de acesso ao RREO, e RGF, que são relatórios de suma importância para a Lei de Transparência da Gestão Pública.

Tabela 3: Item Organização de pastas e arquivos

\begin{tabular}{l|c|c}
\hline RREO & $\begin{array}{c}\text { Organização de arquivos e } \\
\text { e RGF }\end{array}$ & Disponibilizam \\
\hline PPEO & $\begin{array}{c}\text { O sistema gera relatório } \\
\text { de referência } \\
\text { consolidado e em ordem de } \\
\text { data }\end{array}$ & $8-40 \%$ \\
\hline PPEO & $\begin{array}{c}\text { Cumpre-se o prazo de } \\
\text { publicação }\end{array}$ & $2-10 \%$ \\
\hline
\end{tabular}

Fonte: Da pesquisa (2017)

A organização desses arquivos, em quase sua totalidade foi colocada em sistema de filtro de datas por ano.

Tabela 4: Item Publicação

\begin{tabular}{c|c|c}
\hline RREO & $\begin{array}{c}\text { Publicação bimestral desde maio } \\
\text { de } 2010\end{array}$ & $1-5 \%$ \\
\hline RGF & $\begin{array}{c}\text { Publicação quadrimestral desde } \\
\text { maio de 2010 }\end{array}$ & $1-5 \%$ \\
\hline PPEO & $\begin{array}{c}\text { Pormenorizada vem sendo } \\
\text { realizada desde maio de 2010 }\end{array}$ & $0-0 \%$ \\
\hline
\end{tabular}




\section{Observatório}

ISSN n² 2447-4266

Vol. 5, n. 1, Janeiro. 2019

DOI: http://dx.doi.org/10.20873/uft.2447-4266.2019v5n1p396

Fonte: Da pesquisa (2017)

Maioria dos sites não disponibiliza publicação dos relatórios a partir 2010, quando entrou em vigor a Lei de Transparência na Gestão Pública.

Tabela 5: Item Organização e Entendimento

\begin{tabular}{l|c|c}
\hline RREO & $\begin{array}{c}\text { Organização dos arquivos } \\
\text { contábeis é de fácil } \\
\text { entendimento }\end{array}$ & Disponibilizam \\
\hline RGF & $\begin{array}{c}\text { Organização dos arquivos } \\
\text { contábeis é de fácil } \\
\text { entendimento }\end{array}$ & $7-35 \%$ \\
\hline Fonte: Da pesquisa (2017)
\end{tabular}

A maioria dos sites não possuem organização ou documentos de fácil compreensão para o pesquisador. Esse se torna um dos maiores problemas encontrados nos sites. E esse impasse só aumenta, devido à necessidade de definições orçamentárias e senhas no ato da pesquisa.

Tabela 6: Acesso sem senhas e definições orçamentárias

\begin{tabular}{l|c|c}
\hline RREO & $\begin{array}{c}\text { Acesso sem filtros ou } \\
\text { necessidade de definição de } \\
\text { classificação orçamentária }\end{array}$ & Disponibilizam \\
\hline RGF & $\begin{array}{c}\text { Acesso sem filtros ou } \\
\text { necessidade de definição de } \\
\text { classificação orçamentária }\end{array}$ & $3-15 \%$ \\
\hline PPEO & $\begin{array}{c}\text { Acesso sem filtros ou } \\
\text { necessidade de definição de } \\
\text { classificação orçamentária }\end{array}$ & $6-30 \%$ \\
\hline
\end{tabular}

Fonte: Da pesquisa (2017)

Visto que maioria dos sites não organizam relatórios em pastas e arquivos, a maioria disponibiliza o sistema de filtros para encontrá-los. Apenas $15 \%$ dos sites possuem acesso livre nos relatórios RREO e RGF e 30\% no PPEO. 


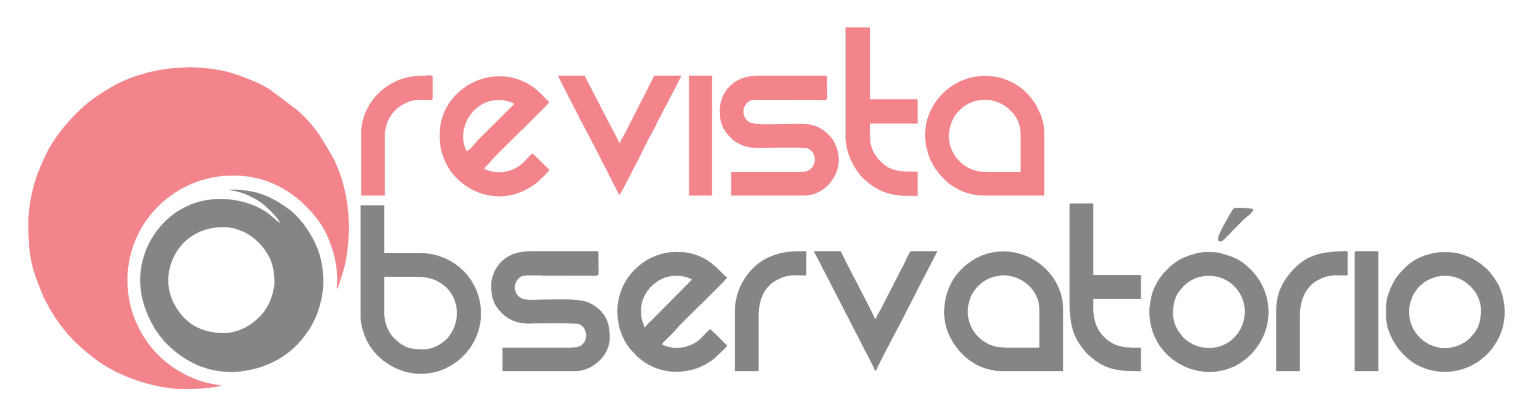

ISSN n² 2447-4266

Vol. 5, n. 1, Janeiro. 2019

DOI: http://dx.doi.org/10.20873/uft.2447-4266.2019v5n1p396

\section{USABILIDADE}

Nesse estudo, reforça-se que o conceito de usabilidade utilizado será:

A usabilidade pode ser definida como o estudo ou a aplicação de técnicas que proporcionem a facilidade de uso de um dado objeto, no caso, um sítio. A usabilidade busca assegurar que qualquer pessoa consiga usar o sítio e que este funcione da forma esperada pela pessoa (BRASIL, 2010, p. 6).

Os sites tiveram, relativamente, boas pontuações no quesito usabilidade. Da máxima de 7 pontos, 15\% deles tiveram pontuação igual ou superior a 4 pontos, e $40 \%$ chegaram a 3,5.

Tabela 7: Item Usabilidade

\begin{tabular}{c|c}
\hline Usabilidade & Disponibilizam \\
\hline Ferramenta de aumento de tamanho & $11-55 \%$ \\
\hline Ferramenta alteração de cor do fundo & $3-15 \%$ \\
\hline Versão do site para línguas estrangeiras & $1-5 \%$ \\
\hline Ferramenta de busca por palavra-chave & $18-90 \%$ \\
\hline Mapa da web site & $10-50 \%$ \\
\hline $\begin{array}{c}\text { Disponível versão do adobe reader para } \\
\text { download }\end{array}$ & $11-55 \%$ \\
\hline
\end{tabular}

Fonte: Da pesquisa (2017)

Tabelo 8: Item Instrumentos de educação fiscal

\begin{tabular}{c|c}
\hline Instrumentos de educação fiscal & Disponibilizam \\
\hline $\begin{array}{c}\text { Cartilha ou manual sobre transparência na } \\
\text { gestão pública }\end{array}$ & $2-10 \%$ \\
\hline $\begin{array}{c}\text { Repositório das peças de planejamento } \\
\text { orçamentário (PPA, LDO, LOA). }\end{array}$ & $7-35 \%$ \\
\hline $\begin{array}{c}\text { Repositório de legislações sobre prestação } \\
\text { de contas e transparência pública }\end{array}$ & $17-85 \%$ \\
\hline $\begin{array}{c}\text { Links de acesso ao TCE, ao Portal } \\
\text { Transparência e ao Controle Interno. }\end{array}$ & $8-40 \%$ \\
\hline Fonte: Da pesquisa (2017).
\end{tabular}

Tabela 9: Item Visibilidade 
DOI: http://dx.doi.org/10.20873/uft.2447-4266.2019v5n1p396

\begin{tabular}{c|c}
\hline Link antes da "dobra de página" & $9-45 \%$ \\
\hline $\begin{array}{c}\text { Contas públicas com apenas um } \\
\text { redirecionamento }\end{array}$ & $12-60 \%$ \\
\hline $\begin{array}{c}\text { O link da seção de prestação de } \\
\text { contas é intermitente }\end{array}$ & $13-65 \%$ \\
\hline
\end{tabular}

Fonte: Da pesquisa (2017).

A maioria dos links da seção de prestação de contas é intermitente, porém quando abertos, surgem os problemas já mostrados anteriormente, como filtros, sublinks vazios, não geram relatórios, etc.

Na Tabela 10 está representado o ranking dos municípios pesquisados e os índices atingidos. Dos sites avaliados, 30\% não possuem pontuação mínima de modo a atender a Lei de Transparência na Gestão Pública. Estão destacados os 3 piores sites na comparação Informação/usabilidade.

Aponta-se como principais problemas o fato de que na maioria dos sites pode-se encontrar links vazios, sem informações financeiras ou que necessitam de muitos filtros.

Tabela 10: Ranking dos municípios pesquisados

\begin{tabular}{l|l|l|l}
\hline \multicolumn{2}{l}{ Transparência Pública } & Usabilidade & Pontuação \\
\hline Município & Pontuação & Município & 5,5 \\
\hline Palmas & 2,50 & Palmas & 5,0 \\
\hline Formoso do Araguaia & 2,00 & Araguaina & 4,0 \\
\hline Guaraí & 1,50 & Paraíso do Tocantins & 3,5 \\
\hline Tocantinopolis & 1,25 & Gurupi & 3,5 \\
\hline Nova Olinda & 1,25 & Peixe & 3,5 \\
\hline Arraias & 1,00 & Guaraí & 3,5 \\
\hline Gurupi & 0,75 & Campos Lindos & 3,5 \\
\hline Taguatinga & 0,75 & Paranã & 3,5 \\
\hline Araguaçu & 0,75 & Alvorada & 3,5 \\
\hline Araguaina & 0,25 & Nova Olinda & 3,5 \\
\hline Paraiso do Tocantins & 0,25 & Taguatinga & 3,0 \\
\hline Campos lindos & 0,25 & Formoso do Araguaia & 3,0 \\
\hline Paranã & 0,25 & Arraias & 2,5 \\
\hline Miranorte & 0,25 & Pedro Afonso & 2,5 \\
\hline Porto Nacional & 0,00 & Araguatins & 2,5 \\
\hline Peixe & 0,00 & Tocantinópolis & \\
\hline
\end{tabular}




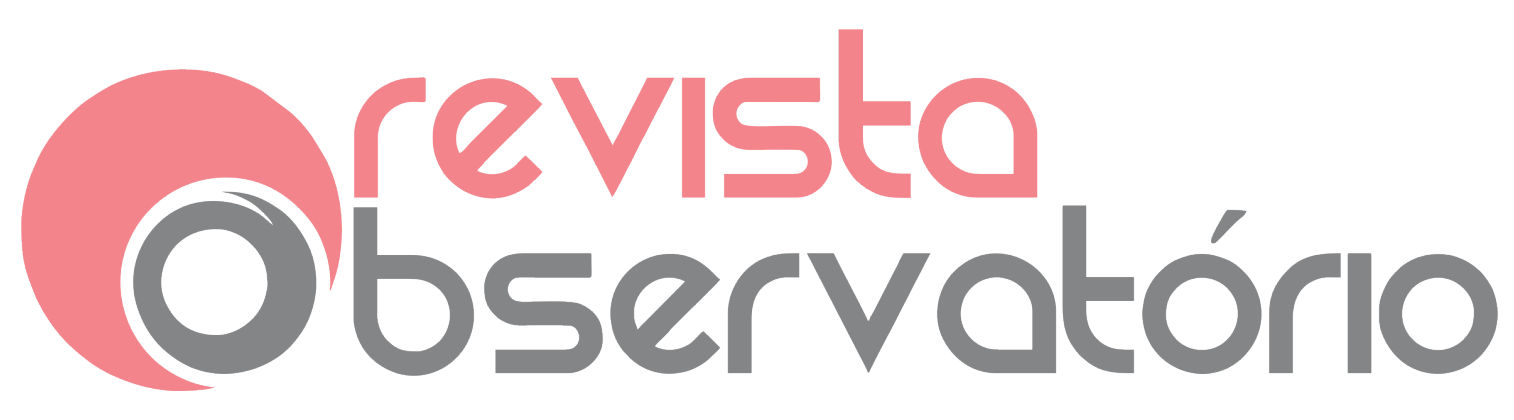

ISSN n² 2447-4266

Vol. 5, n. 1, Janeiro. 2019

DOI: http://dx.doi.org/10.20873/uft.2447-4266.2019v5n1p396

\begin{tabular}{l|l|l|l}
\hline Pedro Afonso & 0,00 & Augustinópolis & 2,5 \\
\hline Araguatins & 0,00 & Miranorte & 2,5 \\
\hline Alvorada & 0,00 & Araguaçu & 1,5 \\
\hline Augustinópolis & 0,00 & Porto nacional & 0,0 \\
\hline Colinas - TO & Não avaliado & Colinas - TO & Não avaliado \\
\hline Miracema - TO & Não avaliado & Miracema - TO & Não avaliado \\
\hline Lagoa da Confusão - TO & Não avaliado & Lagoa da Confusão - TO & Não avaliado \\
\hline Dianópolis - TO & Não avaliado & Dianópolis - TO & Não avaliado \\
\hline Xambioá - TO & Não avaliado & Xambioá - TO & Não avaliado \\
\hline Fonte: Da pesquisa (2017)
\end{tabular}

\section{CONSIDERAÇÕES FINAIS}

O objetivo desta pesquisa foi analisar a efetiva utilização da Internet como um mecanismo promotor da transparência e do acesso à Informação e Dados Públicos, pela população do Tocantins, especificamente por meio dos portais da transparência dos 25 municípios com maior PIB do estado do Tocantins.

A maioria dos municípios disponibiliza, em seus websites, informações sobre os recursos públicos e sua aplicação, embora com volume e qualidade muito aquém do que se espera na era da democracia digital. Os melhores resultados concentram-se na capital Palmas (como esperado) e em duas das maiores cidades. Vários portais nem chegaram a ser avaliados, pois encontravam-se inativos nas datas das consultas.

Diante desses resultados, o estudo visa contribuir para ampliar o estudo sobre o progresso da comunicação digital e da transparência das políticas públicas na internet, colaborando com os gestores públicos do estado e demais, além de contribuir para a prática da participação popular e do controle social, como instrumento de exercício da cidadania. 


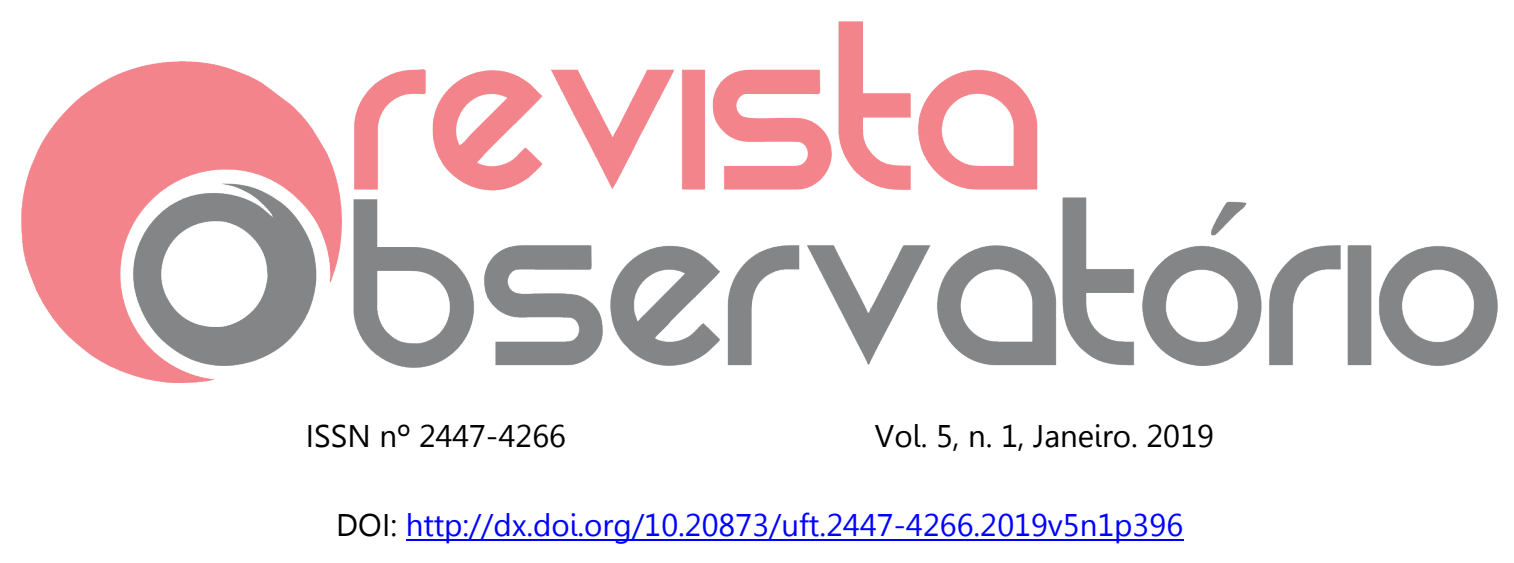

Este estudo pode resultar também no estímulo aos investimentos ou esforços desses governos municipais em ampliar a transparência de suas ações.

Por fim, são propostos alguns estudos posteriores que possam trazer benefícios diretamente relacionados à Administração Pública e à sociedade, como ampliar a pesquisa em municípios de outros estados brasileiros, abrangendo as demais regiões geográficas, para detectar diferenças em relação aos municípios cearenses e sugerir oportunidades de melhorias quanto à transparência digital; repetir a pesquisa nos mesmos municípios buscando verificar a evolução de sua transparência digital e comparar os índices nos municípios brasileiros com os de outros países.

\section{REFERÊNCIAS}

BOBBIO, Norberto, 1998. Dicionário de política, - Brasília: Editora Universidade de Brasília, 10ª ed. 1997.

BOBBIO, Norberto, 1987. Estado, Governo e Sociedade: Por uma Teoria Geral da Política, 4ª Ed. Rio de Janeiro: Paz e Terra, 1987

BRASIL. Constituição da República Federativa do Brasil. Texto de 5 de outubro de 1988 e alterações adotadas pela emendas Constitucionais nos 1/1992 a 55/2007 e pelas Emendas Constitucionais de Revisão nos a 6/1994.

Lei Complementar Federal $\mathbf{N}^{\circ}$ 101, (Lei de Responsabilidade Fiscal), de 04 de maio de 2000. Estabelece normas de finanças públicas voltadas para a responsabilidade na gestão fiscal e dá outras providências. Disponível em $<$ www.planalto.gov.br $>$.

Constituição (1988). Constituição da República Federativa do Brasil: como notas remissivas às principais leis básicas. Atualização e notas por 


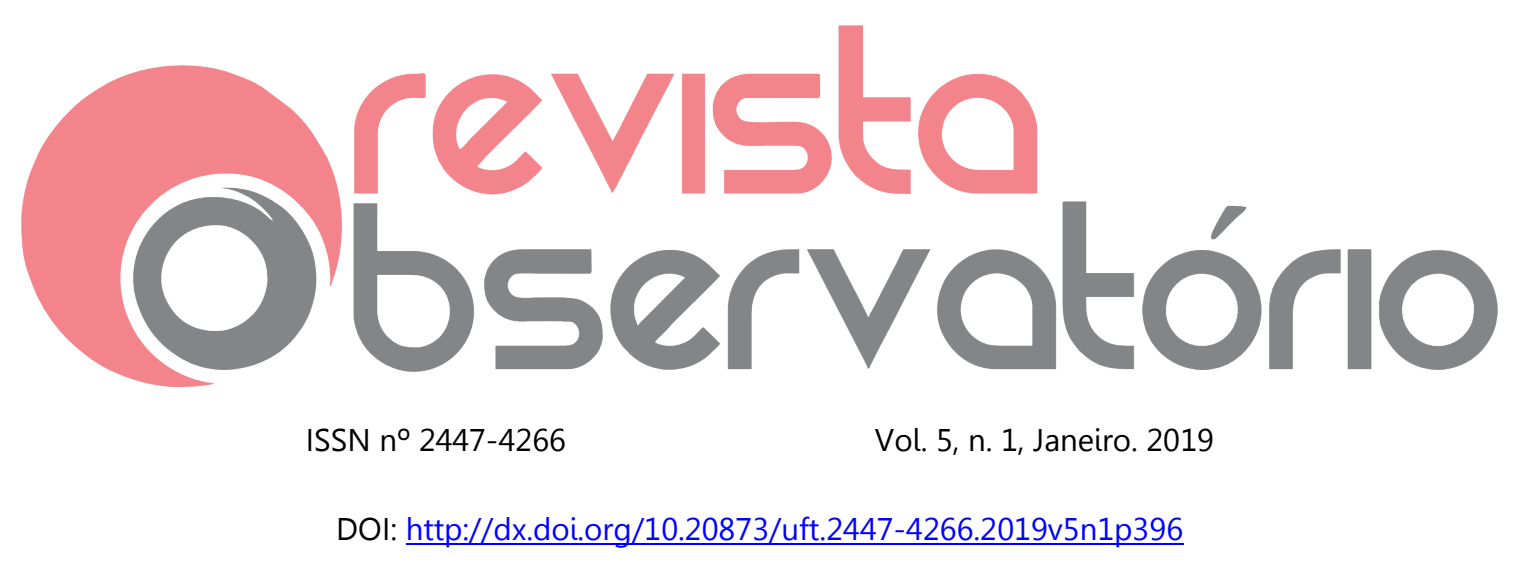

Wladimir Novaes Filho. 10. ed. São Paulo: LTr, 2007. atualizada até a Emenda Constitucional $n^{\circ}$ 53, de 19 de dezembro de 1412006.

. Constituição Federal de 1988. Brasília: Senado Federal (Subsecretaria de Edições Técnicas), 1998.

Emenda constitucional no 19 (04/06/1998). Brasília: Presidência da república. Disponível em <http:///www.planalto.gov.br/ccivil/leis/ LCP/Lcp101.htm>. Acesso em 01/07/2017.

- Lei complementar no 101 (de 04 de maio de 2000). Brasília: Presidência da república. Disponível em <http:///www.planalto.gov.br/ccivil/leis/ LCP/Lcp101.htm>. Acesso em 01/07/2017.

Lei complementar $\mathbf{n}^{\circ} 131$ (de 27 de maio de 2009). Brasília: Presidência da república. Disponível em <http:///www.planalto.gov.br/ccivil/leis/ LCP/Lcp131.htm>. Acesso em 01/07/2017.

Decreto $\mathbf{n}^{\circ} \mathbf{7 . 1 8 5}$ (de 27 de maio de 2010). Brasília: Presidência da república. Disponível em <http:///www.planalto.gov.br/ccivil_03/_Ato2007_2010/ Decreto/D7185.htm>. Acesso em 01/07/2017.

CASTELLS, Manuel. A Sociedade em Rede. Rio de Janeiro: Paz e Terra, 1999.

CHIAVENATO, I. Introdução à Teoria Geral da Administração: Uma visão abrangente da moderna administração das organizações. 7. Ed. Rio de Janeiro: Elsevier, 2003 científica. - 3. ed. - São Caetano do Sul: Yendis Editora, 2008.b

CONDURU, M.T.; RODRIGUES, J.A. Elaboração de trabalhos acadêmicos: normas, critérios e procedimentos. Belém: Edufpa, 2010.

CUNHA, Luiz Antônio. Educação, estado e democracia no Brasil. São Paulo: Cortez; Niterói: Ed.da UFF; Brasília: Ed. Flacso do Brasil, 2003.

DI PIETRO, Maria Sylvia Zanella. Direito Administrativo. 17. ed. São Paulo: Atlas, 2004. 


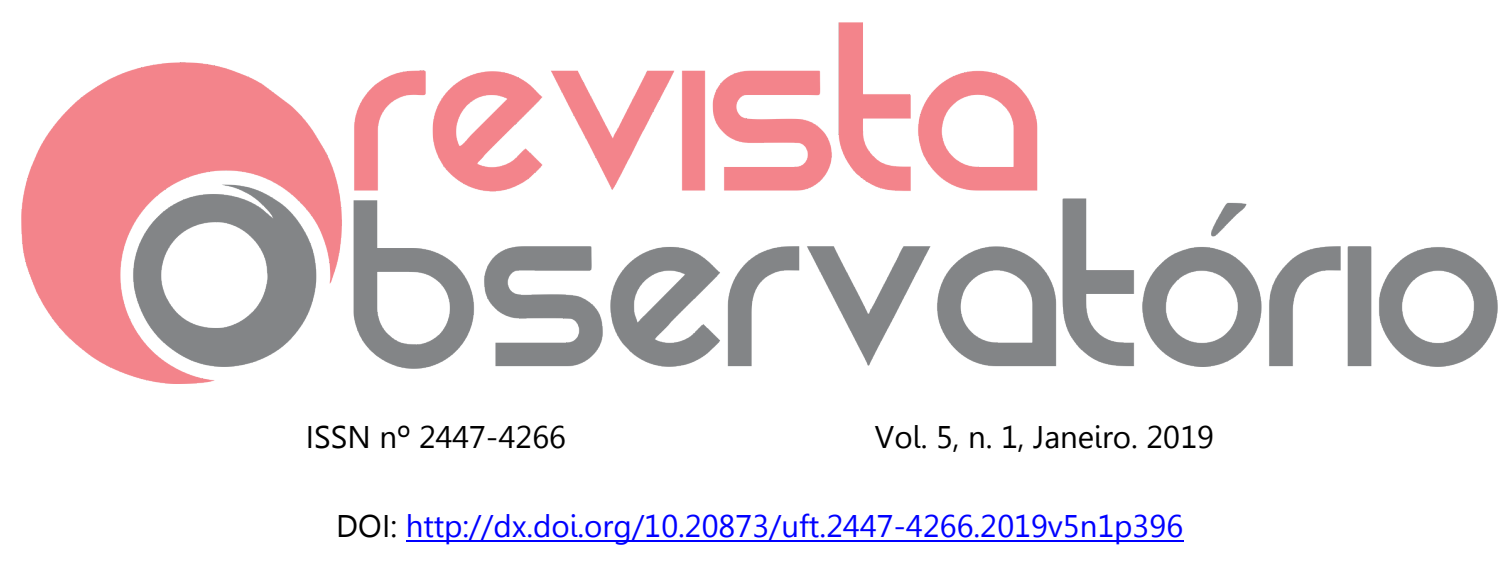

GIL, A. C. Métodos e técnicas de pesquisa social. 9. ed. São Paulo: Atlas, 2001. A.C. Como elaborar projetos de pesquisa. 2. Ed. São Paulo: Atlas, 2002.

HOUAISS, A. Dicionário Houaiss da Língua Portuguesa. Rio de Janeiro: Objetiva, 2009.

IBGE. Cidades. Disponível em: http://cidades.ibge.gov.br/x. Acessado em 26/02/2017.

Portal da transparência. Disponível em: http://www.portaltransparencia.gov.br/. Acessado em 27/02/2017.

LOPES, Luís Sérgio de Oliveira. Ética e Cidadania - Curso de Especialização em Educação Fiscal e Cidadania. Brasília: Escola de Administração Fazendária ESAF, 2008. Apostila.

MANNARINO,R.P. Prestação de contas do governo da República: Para quem? A sociedade brasileira?. Brasília, 2006, p.9. Disponível em <http://portal2.tcu.gov.br/portal/pls/portal/docs/2054232.PDF>. Acessado em: junho de 2011.

MARTINS, G. A.; THEÓPHILO, C. R.. Metodologia da investigação científica para ciências sociais aplicadas. 2.ed. São Paulo: Atlas, 2009.

MATIAS-PEREIRA, José. Manual de gestão pública contemporâneo. 2.ed. São Paulo: Atlas, 2009 Paulo: Atlas, 2010.

José. Manual de metodologia da pesquisa científica. São

NETO, M.C. A transparência e o controle social como paradigmas para a gestão pública no Estado moderno. Administração pública: direitos administrativos, financeiros e gestão pública: prática, inovação e polêmicas. São Paulo: Revista dos Tribunais. 2002. p. 321.

SILVA, Francisco Carlos da Cruz. Controle Social: reformando a Administração para a Sociedade. Bahia. 2005. Disponível em <http://www.revistaoes.ufba.br>. Acessado em: novembro de 2011. 


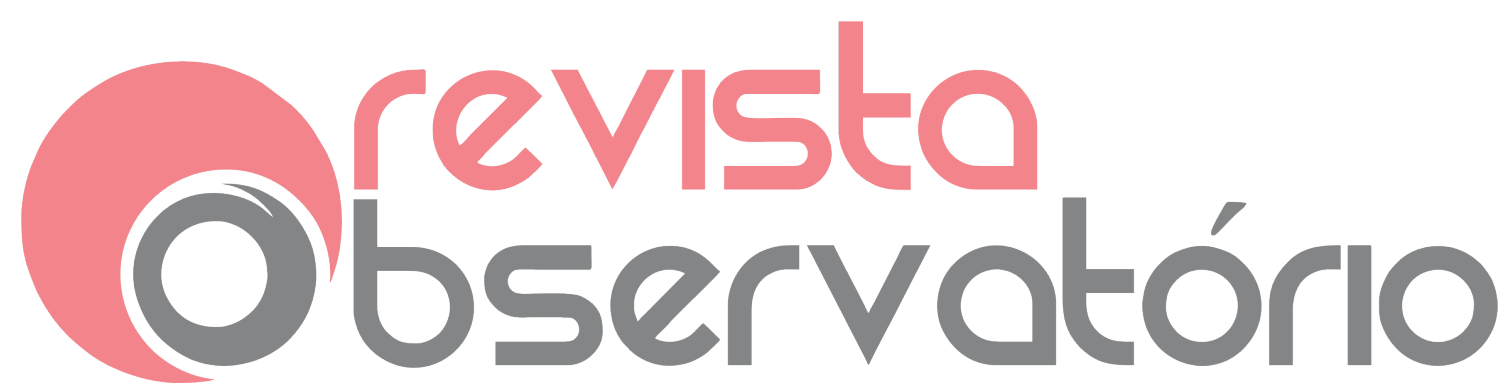

ISSN n² 2447-4266

Vol. 5, n. 1, Janeiro. 2019

DOI: http://dx.doi.org/10.20873/uft.2447-4266.2019v5n1p396

TEIXEIRA, Alberto. A internet na transparência pública municipal: A experiência do estado do Ceará. / Alberto Teixeira: Fundação Konrad Adenauer, 2004. 